Article

\title{
Landslide Hazard and Risk Assessment for a Natural Gas Pipeline Project: The Case of the Trans Adriatic Pipeline, Albania Section
}

\author{
Vassilis Marinos * (D), Georgios Stoumpos and Costas Papazachos \\ Aristotle University of Thessaloniki, School of Geology, Faculty of Sciences, 54124 Thessaloniki, Greece; \\ g_stoumpos@yahoo.co.uk (G.S.); kpapaza@geo.auth.gr (C.P.) \\ * Correspondence: marinosv@geo.auth.gr; Tel.: +30-231-099-8518 or +30-694-483-3898; Fax: +30-231-099-8506
}

Received: 18 December 2018; Accepted: 21 January 2019; Published: 28 January 2019

\begin{abstract}
The paper focuses on the assessment of landslide hazard and risk along or across the Trans Adriatic Pipeline (TAP) natural gas pipeline project in Albania. TAP is a natural gas pipeline that will transport gas from the Caspian Sea to Europe, crossing Northern Greece and Southern Albania. It has long been recognised that landsliding is a major factor for TAP's pipeline route selection in mountainous regions, especially the challenging area of central Albania. Experience from similar major pipelines has shown that hazard avoidance is generally the most costand time-efficient strategy to minimise the landslide risk since geohazard-related decision-making is usually risk-based. For landslides, the risk profile is expected to be dominated by the upslope expansion of existing landslides, resulting in a loss of ridge crest (where the Right of Way (RoW) is usually located), possibly leading to pipeline rupture. However, it is still possible that new landslides could develop under static and/or seismic conditions, especially on steep ridge flanks along the route. An expert determination approach was adopted to define a consensus for the estimate of the risk (i.e., chance of rupture) for the pipeline at eighty-two (82) identified landslide sites in Albania, to identify "hot spots" along the route, where risk-reduction measures could be prioritised. Ten landslides were characterised as "High Risk", fifteen as "Medium Risk" and nineteen as "Low Risk". Following this risk assessment, two large re-routings, as well as several local re-routings, were considered. Further investigation was required to identify the site-specific geotechnical conditions and probable remedial measures in cases where landslides could not be avoided by rerouting.
\end{abstract}

Keywords: landslide; pipeline; hazard; risk; landslide management

\section{Introduction}

Landslides represent a significant hazard for welded steel pipelines because they can generate permanent ground displacements (PGD) along or across the pipeline alignment. PGD are critical for buried pipelines since they must deform axially by bending to accommodate the surrounding ground movements [1]. Pipeline failures caused by landslides often involve full-bore rupture, as opposed to holes and pinhole cracks. As a result, landslide-related incidents tend to result in significant leaks, major environmental impacts and long periods of service disruption [2]. Industry-wide experience is that landslides dominate pipeline rupture statistics in mountainous terrain and should be regarded as a significant operational risk. For this reason, it has long been recognised that landsliding in unstable Right-of-Way (RoW) cut slopes is a major factor in pipeline route selection in mountainous regions, as was the case for Trans Adriatic Pipeline (TAP) in Albania (Figure 1). Experience from other major pipeline systems has shown that avoidance is generally the most cost- and time-efficient strategy to 
minimise landslide hazard, since it is generally not practical to attempt to investigate and stabilise numerous major landslide areas within reasonable project timescales [3]. However, when re-routing is not possible, risk reduction measures can be prioritized after detailed evaluation and analysis of all site conditions.

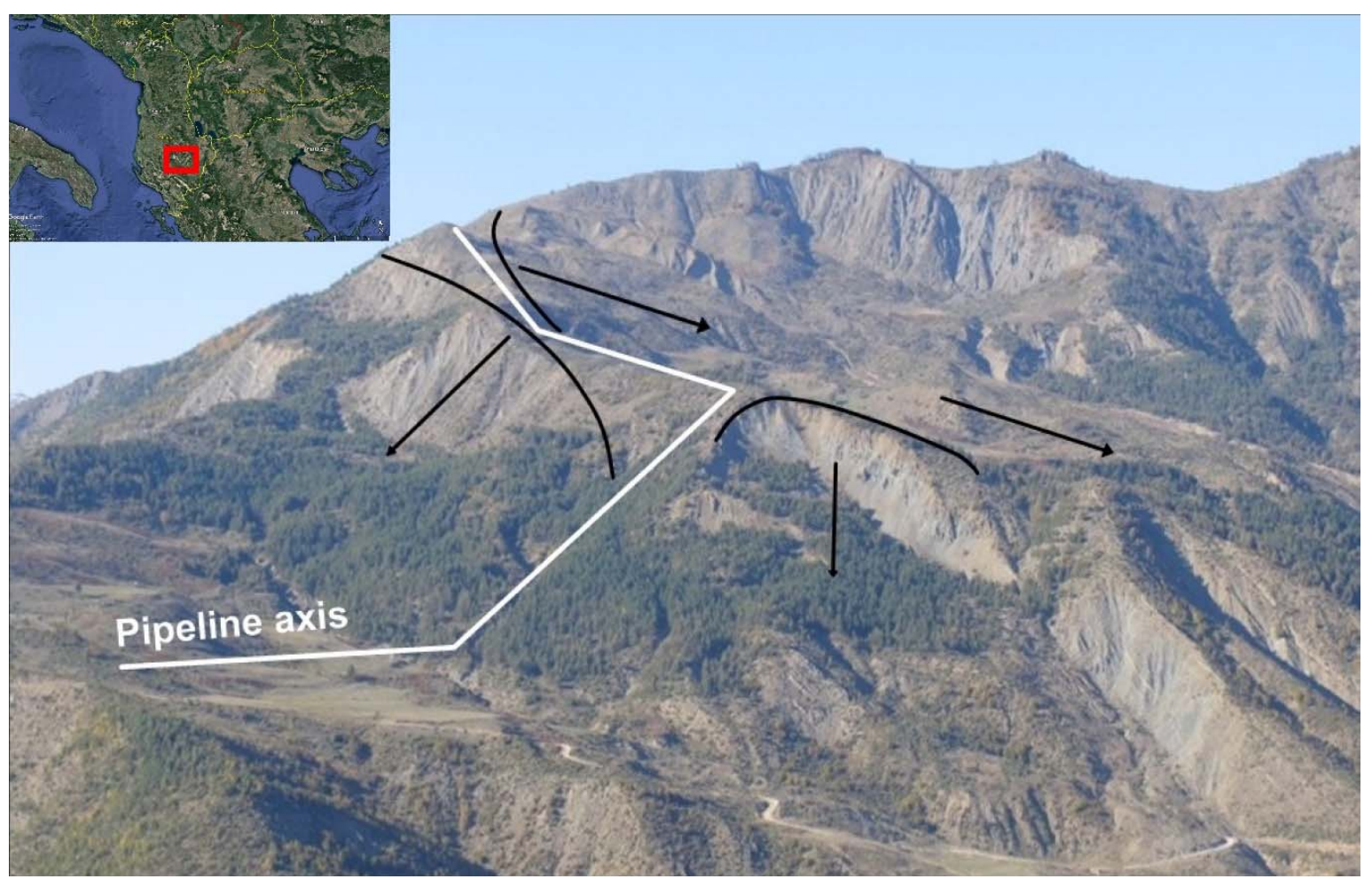

Figure 1. Pre-existing landslides (black lines) along Trans Adriatic Pipeline (TAP) pipeline Right of Way (RoW) in a mountainous region of central Albania. It is evident that landsliding constitutes to be a major risk factor for pipeline integrity.

The Trans Adriatic Pipeline (TAP) is a gas pipeline that will transport natural gas from the Caspian Sea to Europe. Its onshore section starts near Kipi on the Greece-Turkey border, where it connects with the Trans Anatolian Pipeline (TANAP), continues through Northern Greece and Southern Albania, and ends near the city of Fier (Figure 2). The project is currently in its construction phase and, once built, TAP will offer a direct and cost-effective transportation route opening up the vital Southern Gas Corridor, a 3500-kilometre-long gas value chain stretching from the Caspian Sea to Europe (www.tap-ag.com). The total length is $878 \mathrm{~km}$, while its highest elevation will be $1800 \mathrm{~m}$ in the mountains of Albania.

Across Albania, the pipeline crosses the Pindus mountain range, a rather challenging environment for the construction of the project. We focus on the section that spans approximately 70 to $136 \mathrm{~km}$ (KP70-KP136), following the route from east to northwest. This $66 \mathrm{~km}$ long mountain section in Albania is probably the most challenging onshore section of the SCPX-TANAP-TAP pipeline system, due to the combination of narrow ridge crests, steep terrain, high seismicity, widespread active landslides, unstable side slopes and very limited access (Figure 1). 


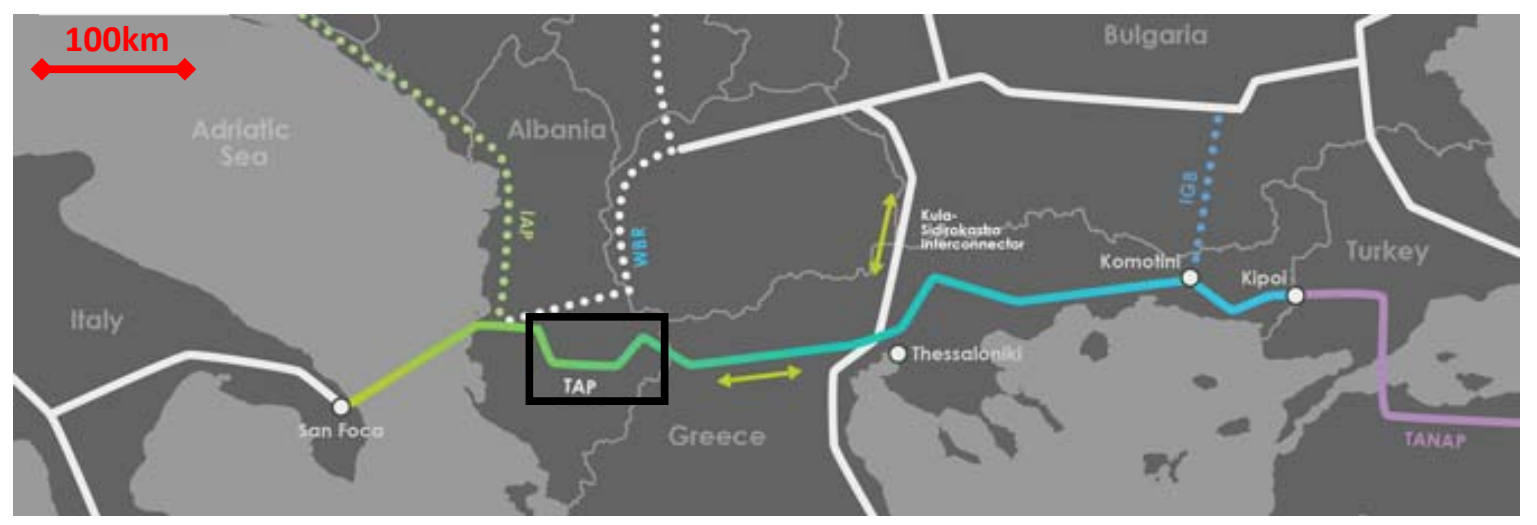

Figure 2. The schematic TAP route. The study area (shown with a black rectangle) spans approximately from $70 \mathrm{~km}$ to $136 \mathrm{~km}$ (KP70-KP136). (www.tap-ag.com).

The pipeline route of TAP in Albania involved numerous landslide areas, since the RoW crossed high and steep slopes, in problematic (from an engineering point of view) geological formations, with weak rock-masses; moreover, the area is characterized by relatively high seismicity, high rainfall precipitation and is a highly erosional environment.

RoW for major gas pipelines is a strip of land, usually between 18 and $36 \mathrm{~m}$ wide, containing one or more pipelines, used as access for inspection, maintenance, testing or emergency (Figure 3). RoW also identifies the area where certain activities are prohibited to protect public safety and the integrity of the pipeline. Steel pipes are towed by truck to the site, where a trench is dug for the pipeline. Trenchless techniques may also be applied when necessary (e.g., avoidance of a landslide, river crossing, and other instances), using boring/jacking, auger bore, HDD (horizontal directional drilling) and micro-tunnelling.

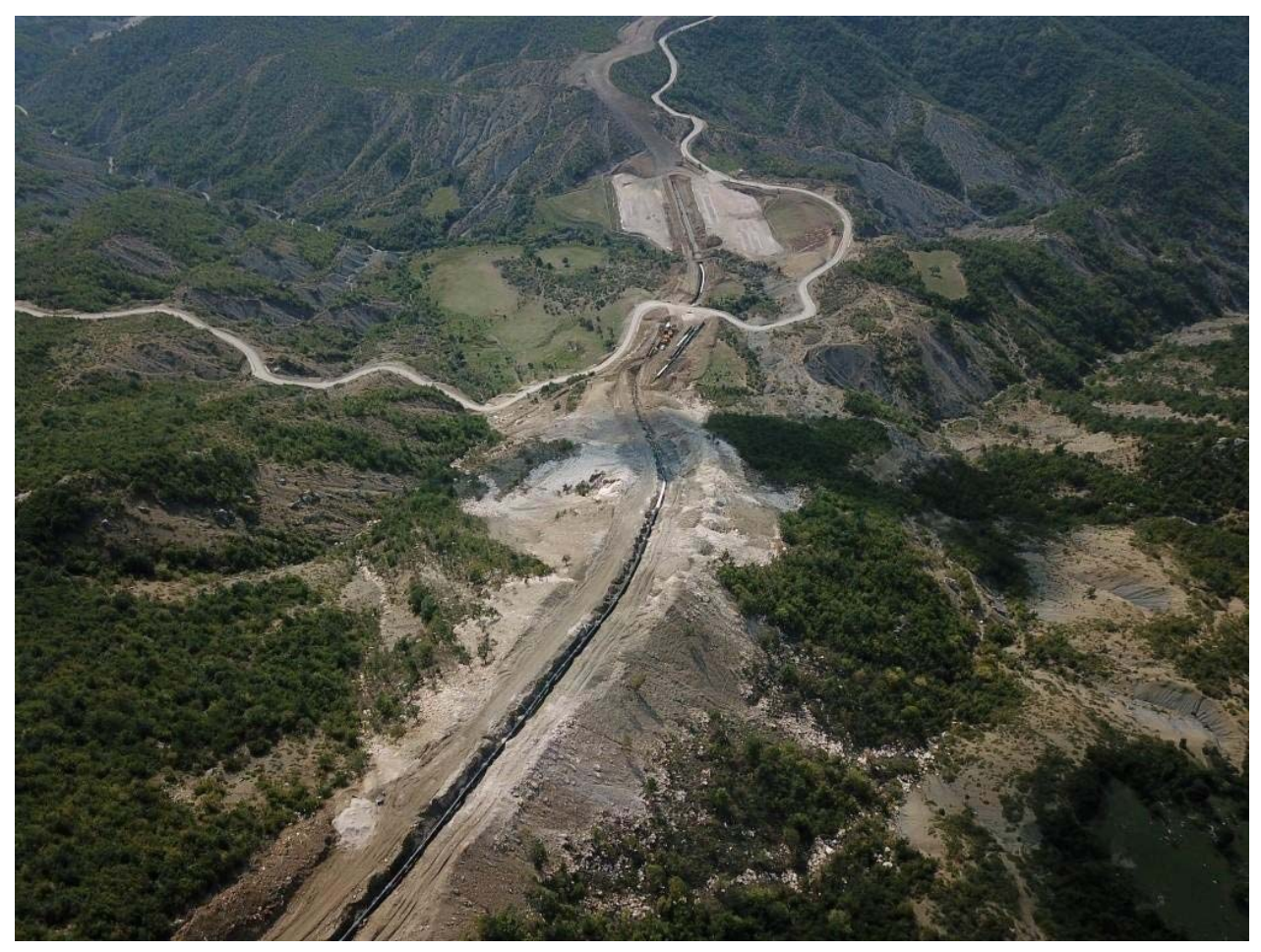

Figure 3. Right of Way (RoW) for major gas pipelines is a strip of land, usually between 18 and $36 \mathrm{~m}$ wide, containing one or more pipelines, used as access for inspection, maintenance, testing or emergency. 
Initially, in the framework of the seismic hazard study, 27 areas had been qualitatively characterised as problematic (i.e., potentially unstable), based on Google Earth pictures. On the basis of the geological conditions prevailing in the area verified by a preliminary field survey (June 2014), as well as the results of the seismic design study, it has been concluded that additional "problematic areas" may exist along the pipeline route along the mountainous section in central Albania. Following the initial field work, two large field surveys in November 2014 and April/May 2015 were performed along the pipeline route. Moreover, a ground investigation program was executed consisting of sampling boreholes, laboratory and in-situ testing, with the installation of inclinometers and piezometers.

From these field surveys but also the study of images from Google Earth, new landslide geohazard areas were identified, and previously characterised landslide geohazard areas were confirmed, delineated or discarded, resulting in the final identification of 82 landslides possibly affecting the specific TAP section. This procedure also allowed to avoid significant landslides and finalize the preferred route for the TAP RoW. More specifically, in line with international best practice, landslide features were identified and avoided by routing along ridge crests and spurs, minimising the exposure to potentially unstable, steep side slopes [3]. Unfortunately, due to the nature of the rugged terrain, the TAP route passes in close proximity $(<50 \mathrm{~m})$ to known landslides on ridge flanks and slopes that are believed to have the potential to fail at some point in the future. As a result, it has not been possible to completely eliminate the exposure to landslide risks by rerouting.

Not all landslide events that reach the pipeline should be expected to cause a rupture within the lifetime of the project. Some may only lead to exposure, while in other cases, the damage may be limited to bending or buckling. A number of simple failure criteria have been developed for this pipeline, based on industry experience $[4,5]$ and limited, finite element modelling of the TAP pipeline response to landslide events. These are either lateral and vertical displacement or spanning (pipeline rupture as a result of the removal of support along a significant length, assumed to be greater than $30 \mathrm{~m}$ for the TAP pipe characteristics) or loading (Figure 4). Most of the investigated cases present spanning failure (up to $80 \%$ ), while some show lateral displacement (up to $10 \%$ ) and loading (up to $10 \%)$ failure modes.

Mapping of landslides and the assessment of susceptibility, hazard and risk have been widely treated in the literature [6-9]. Landslide-risk mapping should be based both on spatiotemporal data, as well as on landslide damaging potential. The landslide body is a sound representation for landslide magnitude [10-12], landslide intensity according to velocity, dimensions, typology, etc., constitutes a more realistic approach $[13,14]$, while the frequency of occurrence and evolution of landslides has normally been established from inventories of historical events [10,15-17]. Quantitative risk assessment has been presented by several researchers $[6-8,18]$.

The approach adopted in this work for the assessment of the pipeline risk due to landsliding followed best practices for landslide risk assessment as described in Fell et al. [8]. The assessment of landslide risk to remote region pipelines typically faces a number of major challenges, such as the limited knowledge of historical landslide activity, the limited information on the causal factors (e.g., earthquakes, high groundwater levels) associated with landslide activity along the pipeline route and the uncertainty over landslide-pipeline interaction. These knowledge-based uncertainties dictate that estimates of landslide risk must be based on expert judgement rather than objective factual statements (e.g., [4]). Nevertheless, since slope stability depends strongly on the expected earthquake loading, a detailed geotechnical investigation followed by slope stability analyses had to be performed for critical slopes that have initially been identified by expert judgement. 


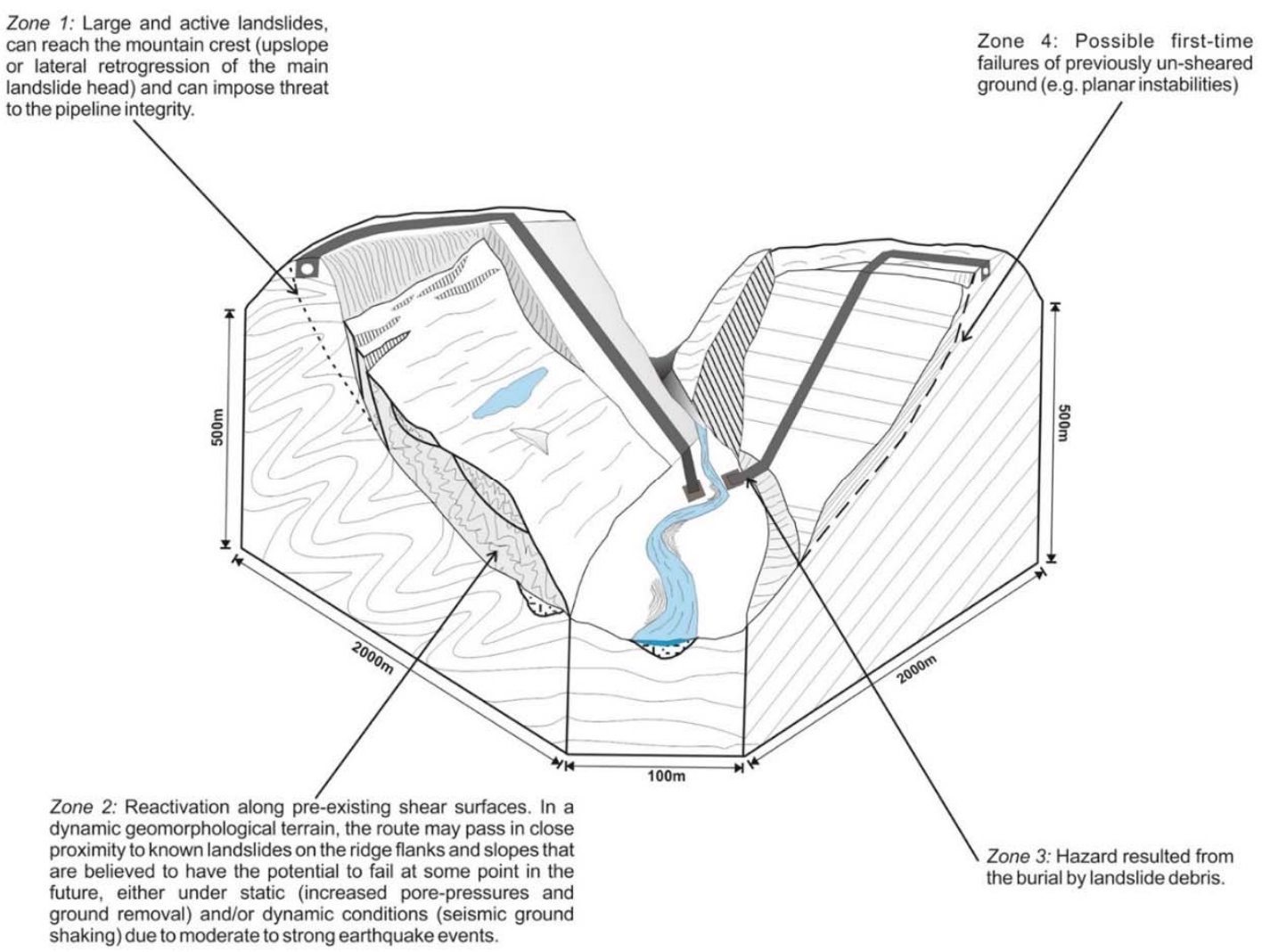

Figure 4. Possible failure event scenarios associated with pipeline rupture.

For the overwhelming majority of examined sites, the available information was limited to the findings of the geological/geomorphological field inspections (i.e., surface forms, current activity state and expected rock mass quality, etc.). Knowledge of the detailed sub-surface conditions (i.e., geology and groundwater) was based on 25 boreholes from the study area. Static and seismic slope stability, as well as pipeline verification analysis, has been indicatively performed for seven sites, to understand how these landslides may threaten pipeline integrity.

The analysis in the present work provides an assessment of the hazard and risk level for the pipeline due to potential landslides and demonstrates how these results can be used to identify "hot spots" along the route where risk reduction measures could be prioritised. The assessment was based on a critical review of the landslide and slope stability information that was available at the time for each of the 82 landslide sites that had been identified along the route. However, this approach is not a substitute for the more detailed site evaluation that would be required to support the design and construction of mitigation measures at critical slopes according to the provisions of EN1997 and EN1998. On the other hand, while analytical methods may be preferred over qualitative methods, the presented assessment can be of interest for practitioners and geohazard consultants working with similar pipeline projects, as it presents a realistic and reasonable expert-based decision tree to grade landslides into different classes of risk, especially when tight schedules and limited geotechnical data information (something typical for extended lifelines, such as gas pipelines) do not allow a more elaborate and quantified assessment. 


\section{General Geological Conditions}

The study area terrain is mountainous, as it is situated in the region between the Korçë plateau and the Osum valley, with an altitude range approximately from 300 to $1800 \mathrm{~m}$. The geological environment of the area is dominated by flysch formations (Figure 5). Limestones and ophiolites (peridotites) were also identified at the eastern edge. The geological environment of the investigated mountain section is dominated by flysch formations. Flysch is not a rock, it is a formation that is associated with orogenesis since it ends the cycle of sedimentation of a basin before the paroxysm folding process. It comprises rhythmic alternations of sandstone and pelitic (siltstones, silty or clayey shales) layers. Conglomerate beds may also be included. It is generally highly tectonized, characterized by intense folding, heavily shearing with numerous overthrusts. Flysch is a weak and complex geological formation, consisting of alternations of competent/strong sandstone layers and low-strength, siltstone/clayey-schist beds. The tectonic disturbance has a profound effect on this formation, as it transforms the initial structure and can produce tectonic mixtures. Degradation due to shearing and fissuring is also very common. The presence of clayey formations, weathering of silty-clayey members, susceptibility to slaking and groundwater also downgrades the formation behaviour. Limestones and ophiolites (peridotites) were also identified at the eastern edge of the study area (Figure 5). Ophiolites, that have a limited presence along the route, are thrust upon the flysch formations and, thus, the latter are highly tectonized, characterised by intense folding and heavy shearing with numerous overthrusts. As a result, flysch is landslide-prone because of its low strength, deformed and tectonically sheared rock-mass, weak siltstones and clay-rich beds.

A combination of weak rocks, steep slopes, rainfall and snowmelt, as well as strong expected ground accelerations from earthquakes creates a difficult environment, prone to landsliding for the study area (Figure 6). The TAP RoW in this area mainly lays along mountains ridges and is typical to run over steep to very steep slopes and areas delineated by landslides.

The seismicity of the Albanian sector of the TAP is well documented in Figure 7. The peak ground bedrock acceleration (PGA) is $0.4 \mathrm{~g}$, with a $10 \%$ probability of exceedance in 50 years ( 475 year return period), while the average annual rainfall ranges from 1500 to $2000 \mathrm{~mm}$. Earthquakes are mainly distributed along the coast, and there are two earthquakes with an MW larger than, or equal to, 7.0 (red) in the area. The area around Durres and Tirana is seismically active with a large number of events with magnitude 6 and over (orange). Fortunately, the seismicity along the pipeline route seems to be generally lower than elsewhere, but there are some earthquakes of an MW 6 (orange) near the TAP corridor. 


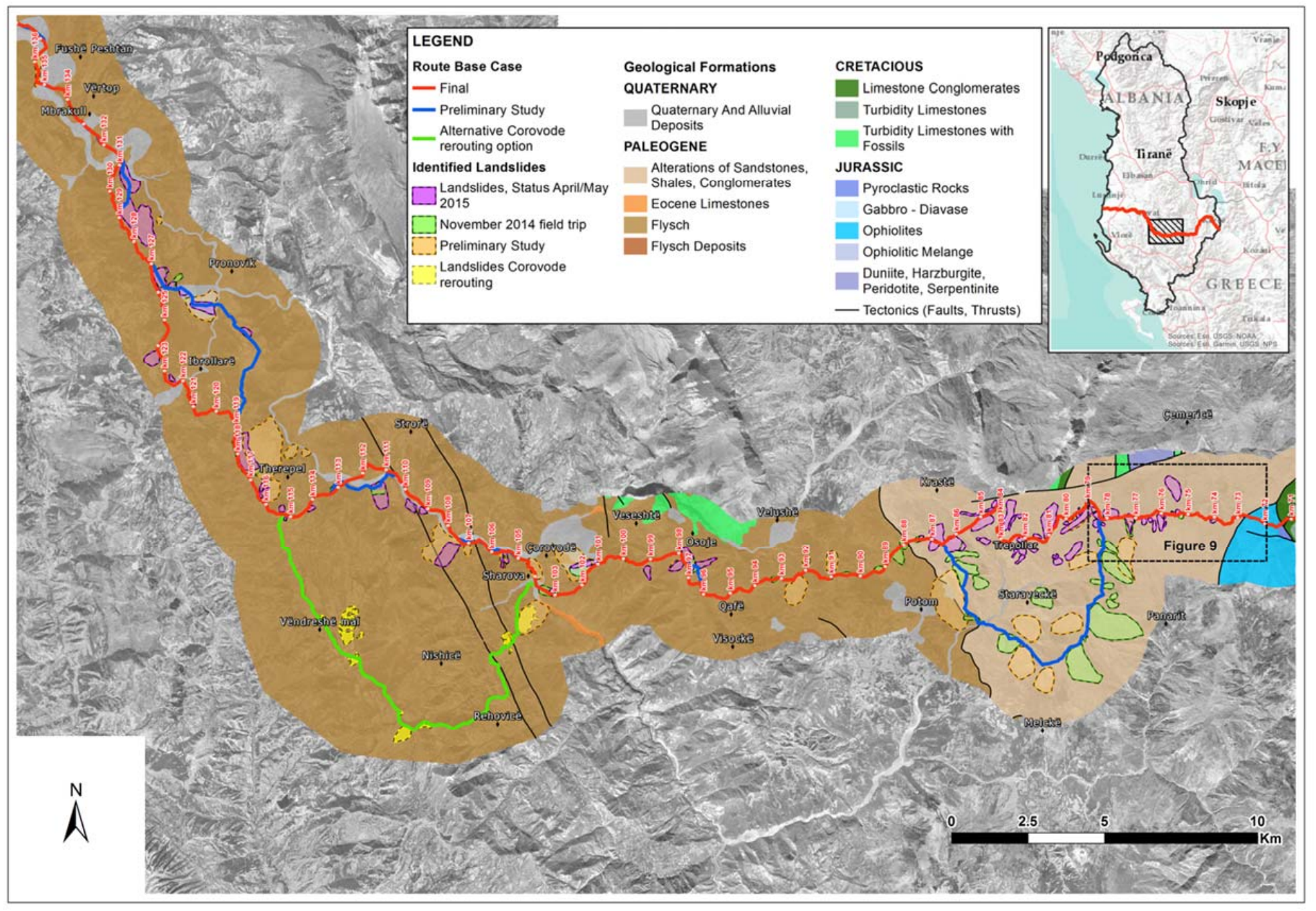

Figure 5. Geological conditions along the Trans Adriatic Pipeline (section 71-136 Km). The geological environment of the area is dominated by flysch formations. Limestones and ophiolites (peridotites) were also identified at the eastern edge. 


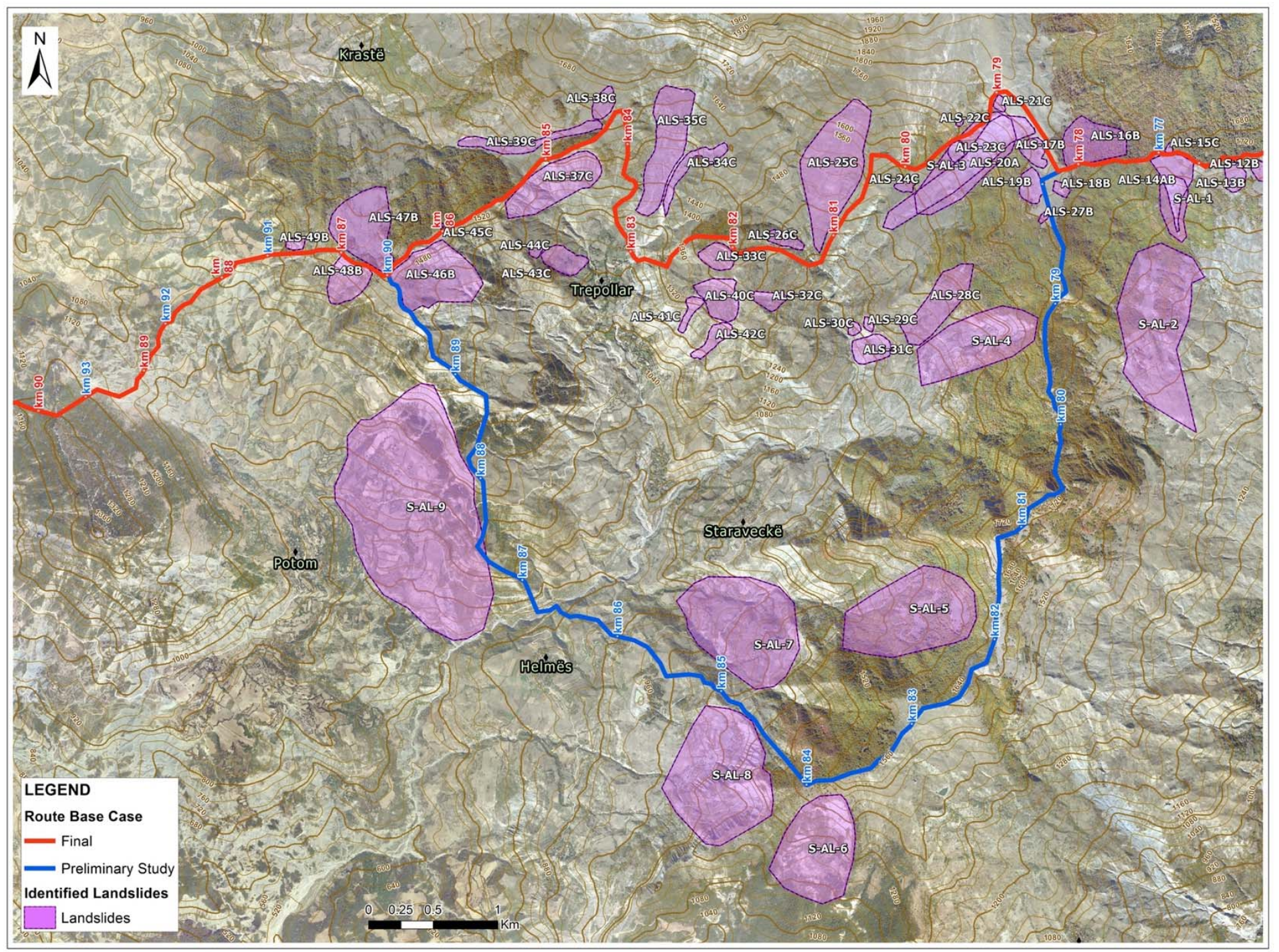

Figure 6. Combination of weak rocks, steep slopes, rainfall and snow melt and strong ground accelerations (earthquakes) creates an environment prone to landsliding. 


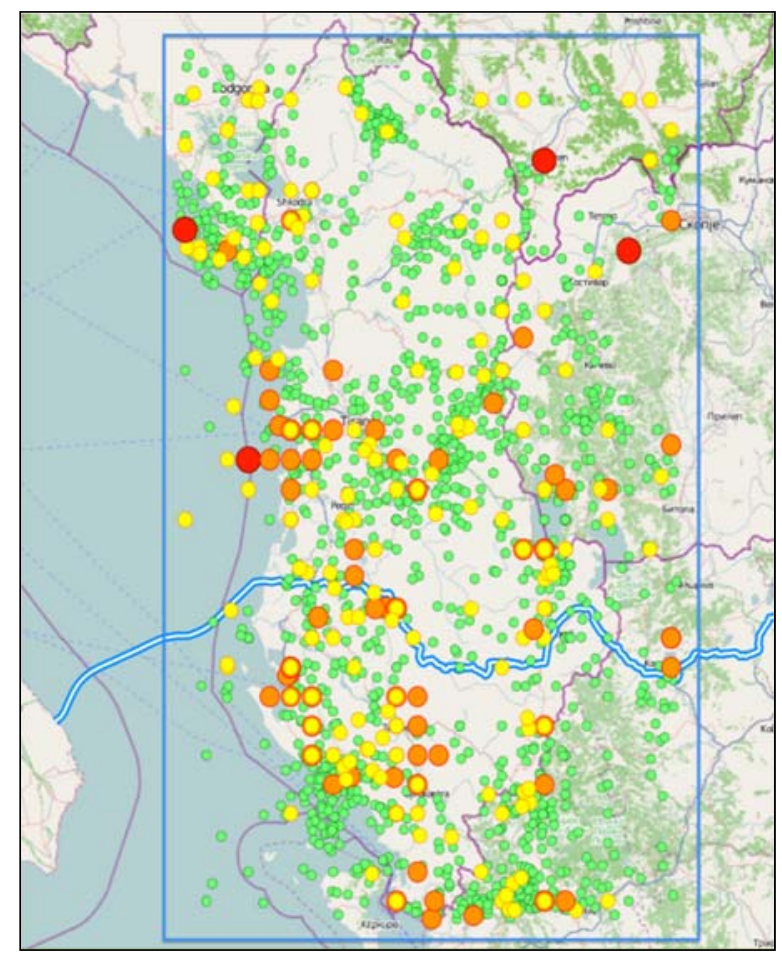

Figure 7. Seismicity for the Albanian sector of the TAP. Earthquakes with an MW 4.0-4.9 are plotted with green symbols, yellow symbols indicate events with an MW 5.0-5.9, the orange symbols MW 6.0-6.9, and the red symbols $\mathrm{MW} \geq 7.0$ [19].

\section{Engineering Geological Conditions}

To understand the ground behaviour developing the previously described significant slope instabilities, a standardisation of the qualitative engineering geological characteristics and the assessment of the slope stability behaviour for flysch rock masses have been performed. Flysch's behaviour is controlled by the tectonic disturbance, the siltstone-sandstone heterogeneity, the weathering degree, the groundwater pressures and the geometry of the main structural features of the rocks. Therefore, the engineering geological evaluation included the following criteria: (i) qualitative characteristics of the rock mass quality (lithology, rock mass structure, weathering, strength, joint characteristics, water presence); (ii) measurements of key structural elements; (iii) geotechnical classification with the GSI system, and (iv) estimation of the weathering profile. For the appreciation and classification of the rock mass quality, we used the extension of the original geological strength index (GSI) application charts for heterogeneous and structurally complex rock-masses, such as flysch (Figure 8). Use of the GSI rock mass classification system and the associated m, $s$ and a parameter relationships linking GSI with the Hoek-Brown failure criterion $[20,21]$ provides a demonstrated, effective and reliable approach for prediction of rock mass strength for surface and underground excavation design and for rock support selection for most normal rock masses.

Along the investigated route, the overall rock mass condition (lithology, structural disturbance, discontinuities) was evaluated from field observations and measurements and used for the engineering geological zonation of the investigated TAP route (shown in Figure 9). 


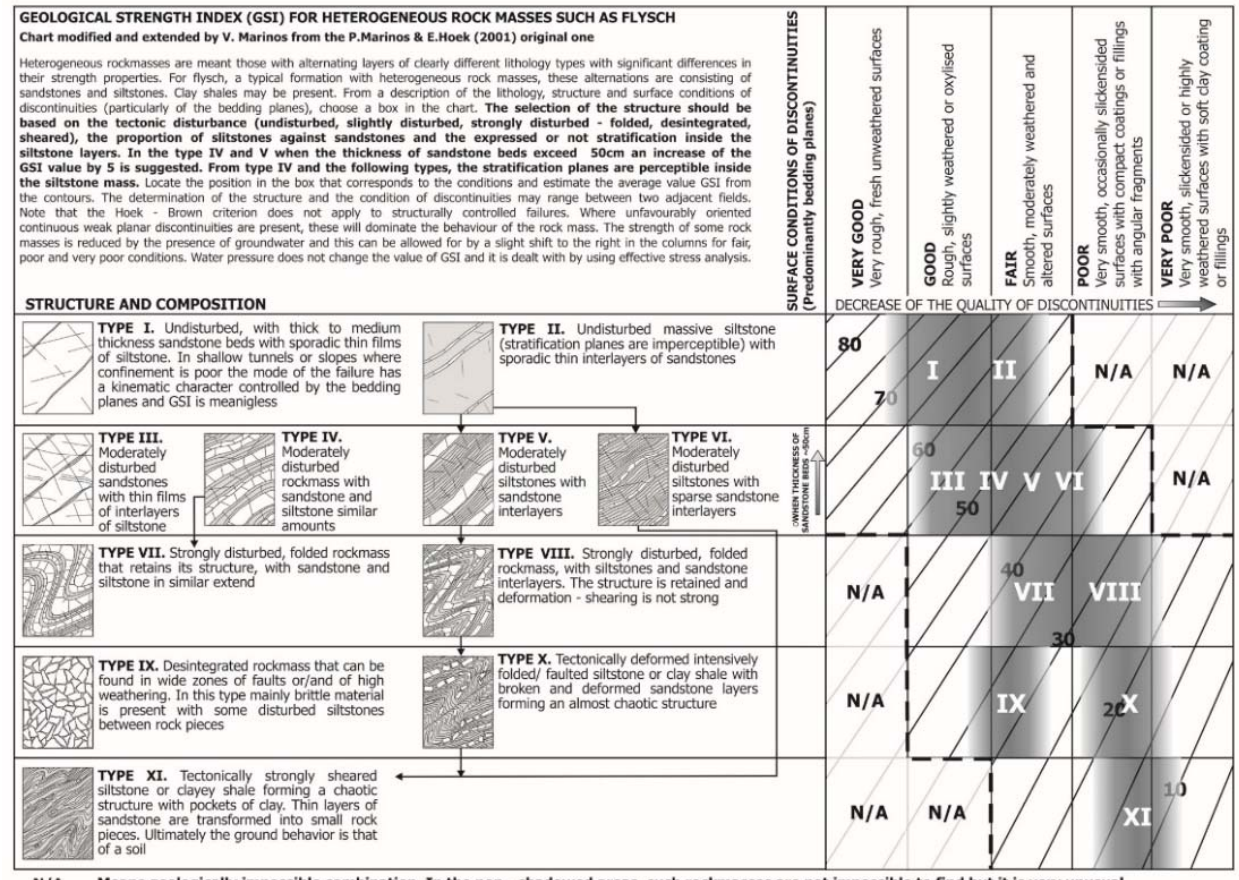

N/A Means geologically impossible combination. In the non - shadowed areas, such rockmasses are not impossible to find but it is very unusua

$\longrightarrow$ Means deformation after tectonic disturbance

Figure 8. Geological strength index (GSI) chart for heterogeneous and structurally complex rock masses, such as flysch used for rock mass quality classification. N/A: Not applicable cases in nature.

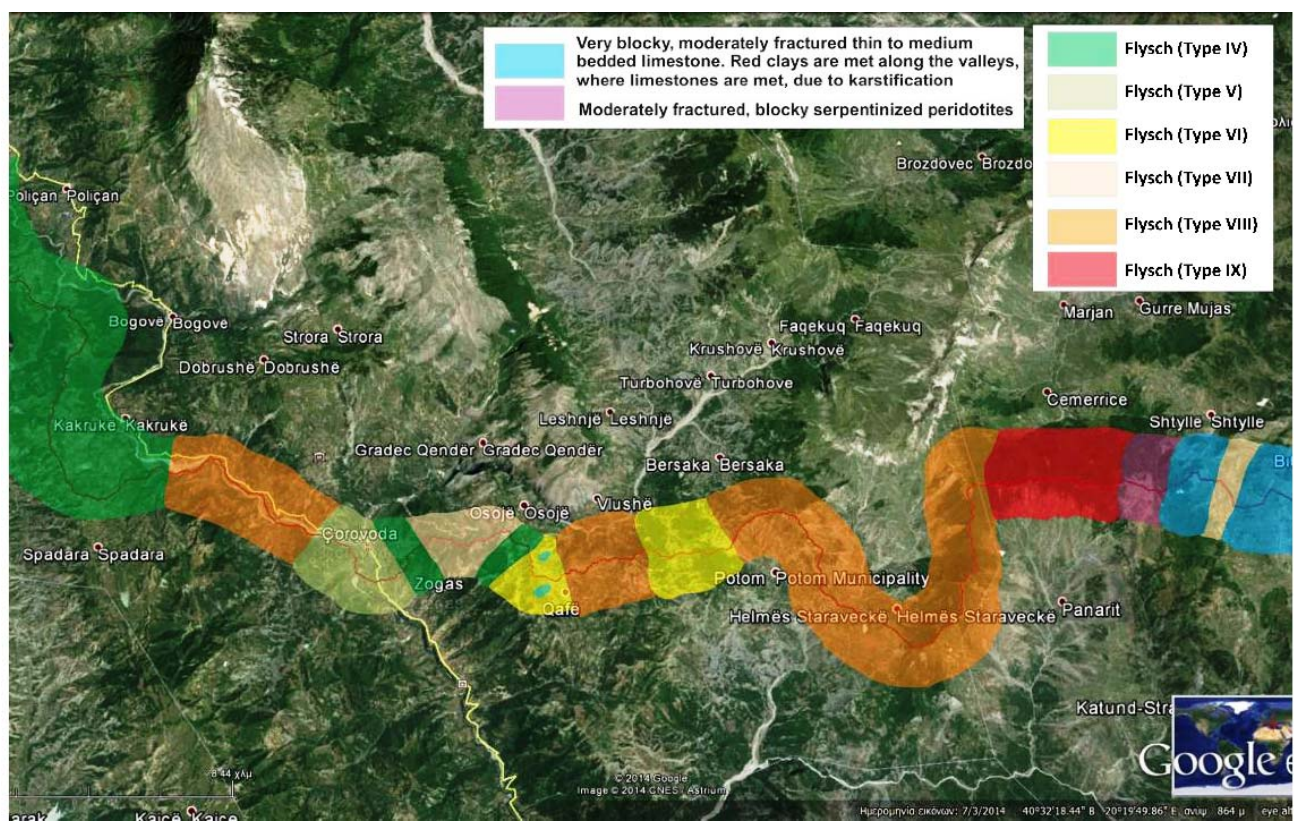

Figure 9. Zonation of the rock mass types and quality along the examined TAP route using the GSI (Figure 8) system for tectonically disturbed heterogeneous rock masses. The areas where most new identified landslides were encountered are characterised by the presence of flysch types VIII (i.e., strongly disturbed siltstones, folded rock mass, with sandstone interlayers) and IX (i.e., tectonically deformed, intensively folded/faulted siltstone with broken and deformed sandstone layers, forming an almost chaotic structure). Limestones (light blue) and ophiolites (peridotites) (purple) were also identified at the eastern edge. The little squares indicate the location of two photos in Figure 10. 

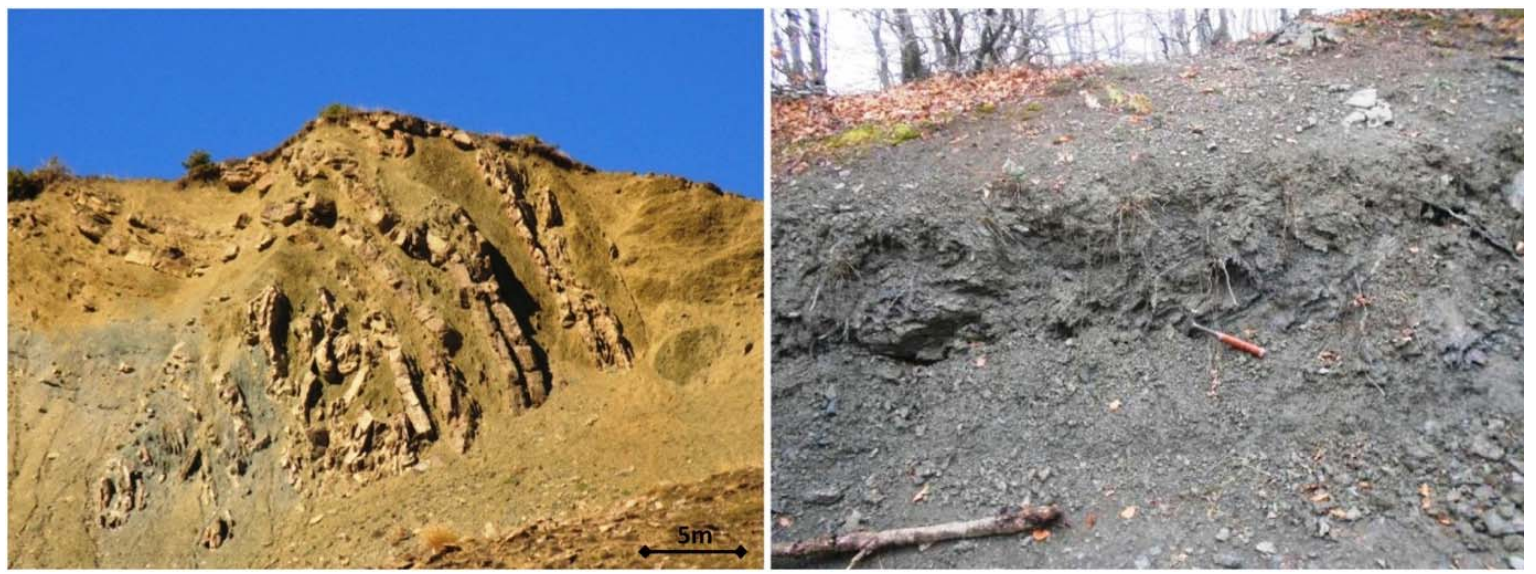

Figure 10. Typical examples of flysch type VIII (left) and flysch type IX (right) at landslide masses.

As seen in Figure 9 and demonstrated in Figure 10, the areas where most new identified landslides were encountered are characterised by the presence of flysch types VIII (i.e., strongly disturbed siltstones, folded rock mass, with sandstone interlayers) and IX (i.e., tectonically deformed, intensively folded/faulted siltstone with broken and deformed sandstone layers, forming an almost chaotic structure).

\section{Landslide Inventory}

\subsection{Landslide Identification}

As earlier noted, a large number of landslides were identified along the TAP route in Albania after several focused field-trip investigations, executed mostly on the ridge along the pipeline route, following a preliminary identification of possible geohazard landslide areas from the topographic maps and satellite imagery.

The work on landslide identification, both at the preparation stage and in field, must be to continuously look for key elements that signify the existence of an active landslide or an unstable area. These key elements are presented in the following paragraphs. It is highlighted, though, that a final assessment of the level of hazard and risk for the pipeline due to potential landslides along the route must be undertaken by experienced geologists.

The desktop study involved three main procedures to prepare an appropriate landslide-prone area inventory.

1. Identification of possible old landslide areas from the topographic maps-Sudden changes of slope angle, flat areas or bulge on slopes (square, vis-à-vis contour lines).

2. Identification of possible old landslide areas from satellite images (from Google Earth in this case)—bare, with no vegetation and/or steep slopes.

3. Identification of surface water ponds and lakes.

Two large field trips took place for the identification of the main landslide geohazards along the TAP base case route, and two focused field trips took place for the investigation of suggested re-routings, to avoid these landslides but also to obtain detailed observations on specified geohazards. The first field survey showed that many more unstable areas existed along the TAP route that could possibly threaten the pipeline integrity than originally assessed from desktop and limited field investigations. The field work was executed mostly on the ridges along the pipeline route, following a primary identification of possible geohazard landslide areas from the topographic maps and satellite images. As a result of a field survey, new landslide geohazard areas were identified and highlighted, while others were delineated or discarded. The "as accurate as possible" adjustment 
of the boundaries of each landslide was very helpful for the selection of the optimum route and for the subsequent risk assessment. The field study involved several procedures and observations, to define the actual spatial, geological and geotechnical features of the finally derived landslide areas. Such observations were:

- Fresh cuts or ruptures along the slope, arch-shape or transversal to it;

- Wide undulating morphological features;

- Deformed vegetation-creep;

- Irregular topography with small hills and back-tilts along the slope;

- Springs, reservoirs of water (small lakes) in the middle of the slope;

- Sudden changes of slope angle, flat areas or bulge on slopes.

Characteristics about the quality of the rock mass (lithology, rock mass structure, weathering and extent of weathering mantle, strength, joint characteristics, water presence) were identified and recorded. For the understanding of the ground behaviour developing the slope instabilities, a standardization of the qualitative engineering geological characteristics and the assessment of the behaviour in slope stability for the identified rock masses were assessed.

A ground investigation campaign comprising of 25 sampling boreholes, the installation of 11 piezometers and 13 inclinometers was also executed as a pilot programme for the landslide study. A monitoring programme with groundwater level measurements and inclinometer recordings supported this assessment. The drilled boreholes were used to identify the nature of the sliding geomaterial, the groundwater regime and the possible sliding depth. The key findings of this investigation concerned some deep-seated $(>20 \mathrm{~m}$ ) landslides, with multiple shear clayey surfaces and high groundwater tables. Data from the field trips, monitoring measurements and ground investigation were subsequently evaluated and incorporated into the inventory of the identified landslides. Parameters pertaining to the geometrical, geological and geomorphological characteristics of each landslide were later associated with the hazard and risk assessment.

\subsection{Landslide Inventory}

Several landslide geohazard areas were spatially extensive, showed recent landslide activity (Figure 11) and could fail even under static conditions. An inventory of landslides was compiled from satellite imagery and field inspection (see Figures 12 and 13). As a result of this mapping, two large re-routings and several small ones were considered for investigation.

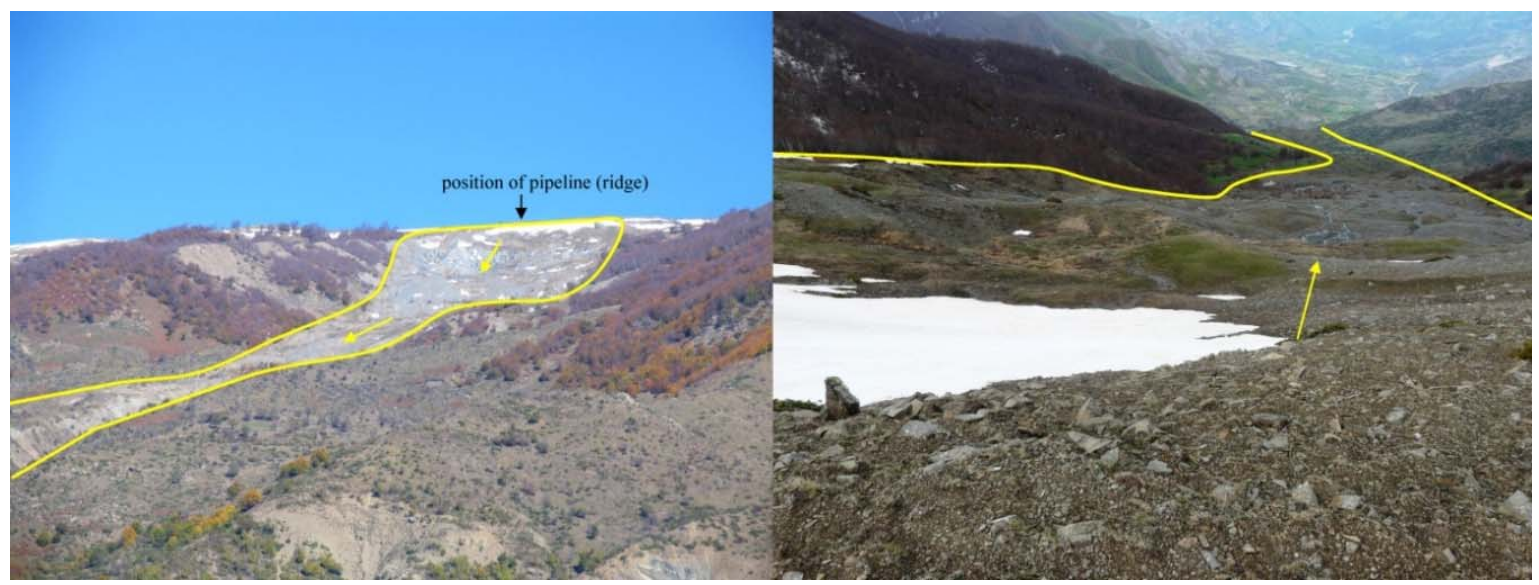

Figure 11. A view of landslide ALS-20A. Upslope view of the crest and landslide mass (left) and downslope view (right) taken from the pipeline RoW. The yellow lines show the landslide (earthflow according to the classification of [22]) boundaries, the yellow arrows the direction of movement and the black arrow indicates the position of the pipeline axis. 


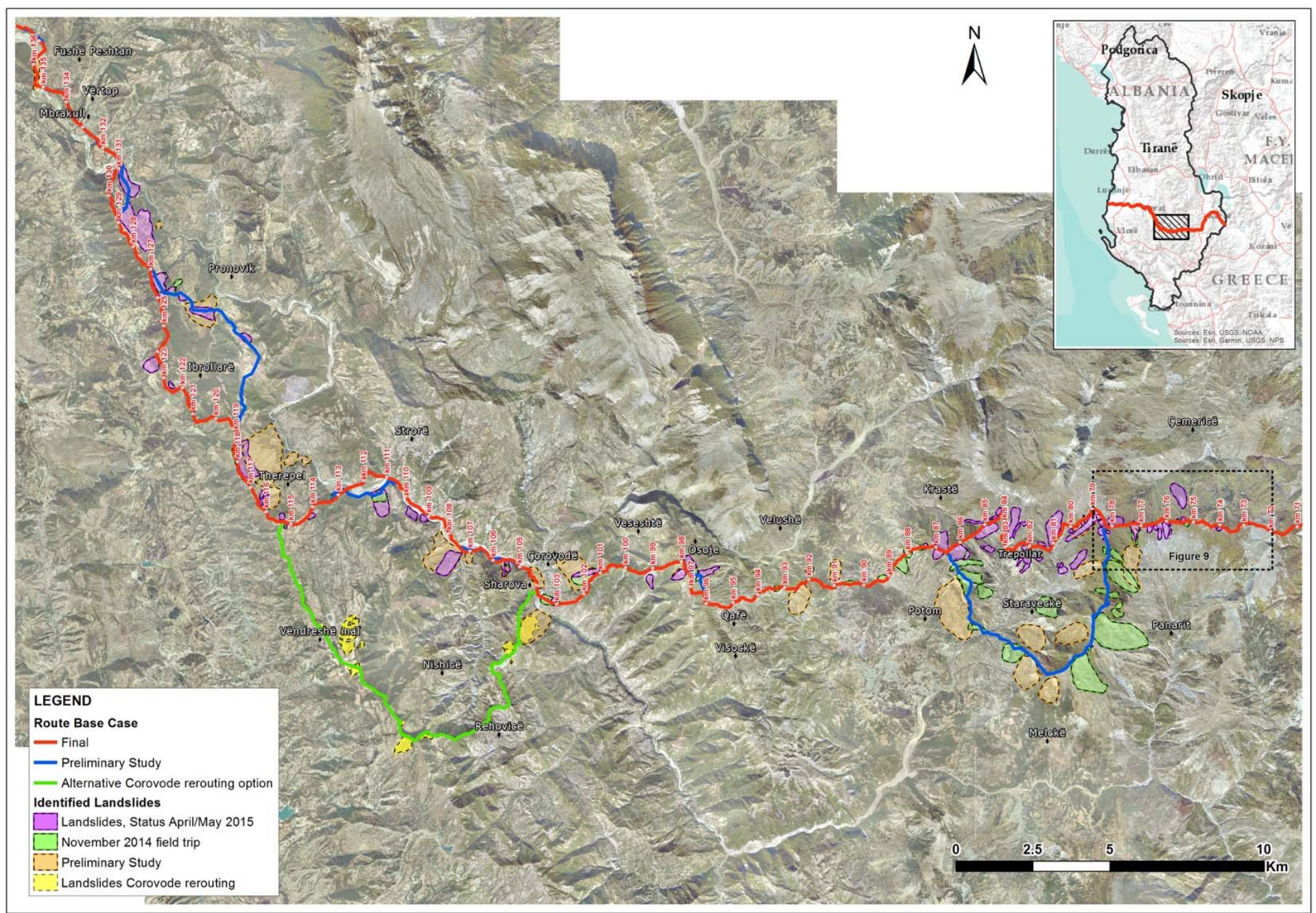

Figure 12. Inventory of 82 landslides compiled from satellite imagery and field survey. Landslides are depicted by polygons (colours indicate different study phases) for the whole area, verifying that landsliding was a major factor for the TAP pipeline route selection in this mountainous region. Different re-routings that were investigated in the field to avoid critical landslides are also presented. 


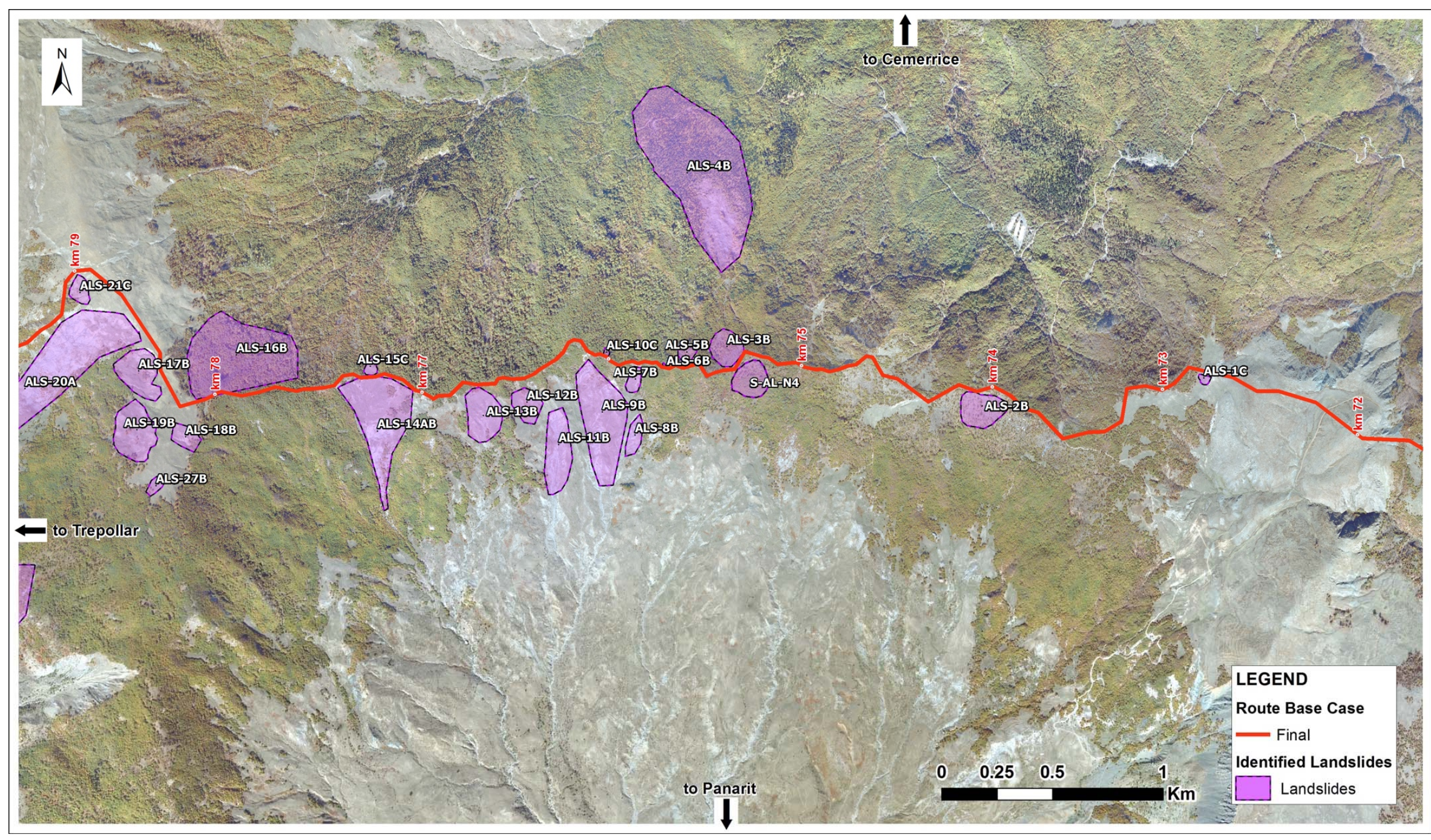

Figure 13. Landslide inventory for the TAP segment between 72 and $79 \mathrm{~km}$, where several landslides are located close to the TAP RoW, threatening pipeline integrity. 
Comprising the previously described condition of the rock masses, combined with significant precipitation in the mountainous area and high seismic motion, the occurrence of translational and rotational landslides as well as creep is fairly common. The slope stability of flysch formations depends on the rock mass heterogeneity, the tectonic history and the regional setting. The identified landslide mechanisms vary along the pipeline route in relation to the degree of weathering of the rock mass, the tectonic disturbance as well as the orientation of the rock mass prevailing discontinuities relative to the slope angle and the orientation. Rotational landslides can occur mainly in rock mass types VI to XI in the GSI chart (Figure 8), where the controlling factors lie on the rock mass strength. Planar landslides can occur in rock mass types I, III, IV, V (Figure 8). The controlling factors are the potential kinematic favorable conditions and shear strength of discontinuities. The bedding planes here are the more essential discontinuities since they persist in space and are often tectonically sheared due to differential movement during folding. Bi-planar landslides could also develop in a combination of weak persisting discontinuities, although in this case, none of persisting major discontinuity families can provoke alone a landslide; one discontinuity is almost always a bedding plane. It is noted that it is not in the scope of the paper to present detailed information of the 81 identified landslides but to present the hazard and risk assessment for the pipeline integrity. Still, some information and examples of the landslides are presented in the next paragraphs.

\section{Landslide Hazard Assessment}

Hazards associated with landslides are determined by the movement type expected to occur, as well as their potential to produce adverse consequences. Two main categories of landslide events can be recognized, all of which can occur in the studied Albanian mountains: (i) Reactivation of pre-existing landslides along pre-existing shear surfaces (Figure 14b), that may also involve upslope or lateral retrogression of the main landslide head (Figure 14a,d), or the downslope advance of debris lobes on the toe area, (ii) New failures of previously unsheared ground, often involving the mobilization of the peak material strength. Tension cracks show possible future landslide movement (Figure 14c).

For an existing landslide or slope to have the potential for future movement there must be a credible initiating event that causes landslide movement, such as increased pore-pressures, seismic ground-shaking, removal of support by erosion of the landslide or slope toe (e.g., by a river or during excavation), loading the head of the landslide or slope (e.g., by the accumulation of debris from hillside avalanches or fill placement during construction). An assessment of slope instability was performed to quantitatively assess such phenomena for all the landslide-prone areas in Albania that could affect the TAP RoW. Whether the "expected" landslide event reaches the RoW and impacts the pipeline is influenced by the nature and size of the expected landslide event (controlled by the site geology and geomorphology), as well as the proximity and position of the existing landslide feature to the pipeline (i.e., upslope, beyond the lateral margin, crossing or downslope of the toe, etc.). For these reasons, the hazard assessment performed in this study (Table 1) was based on several criteria, such as activity status, scale of the landslide, distance from the pipeline, slope steepness, ground quality and sliding depth. 


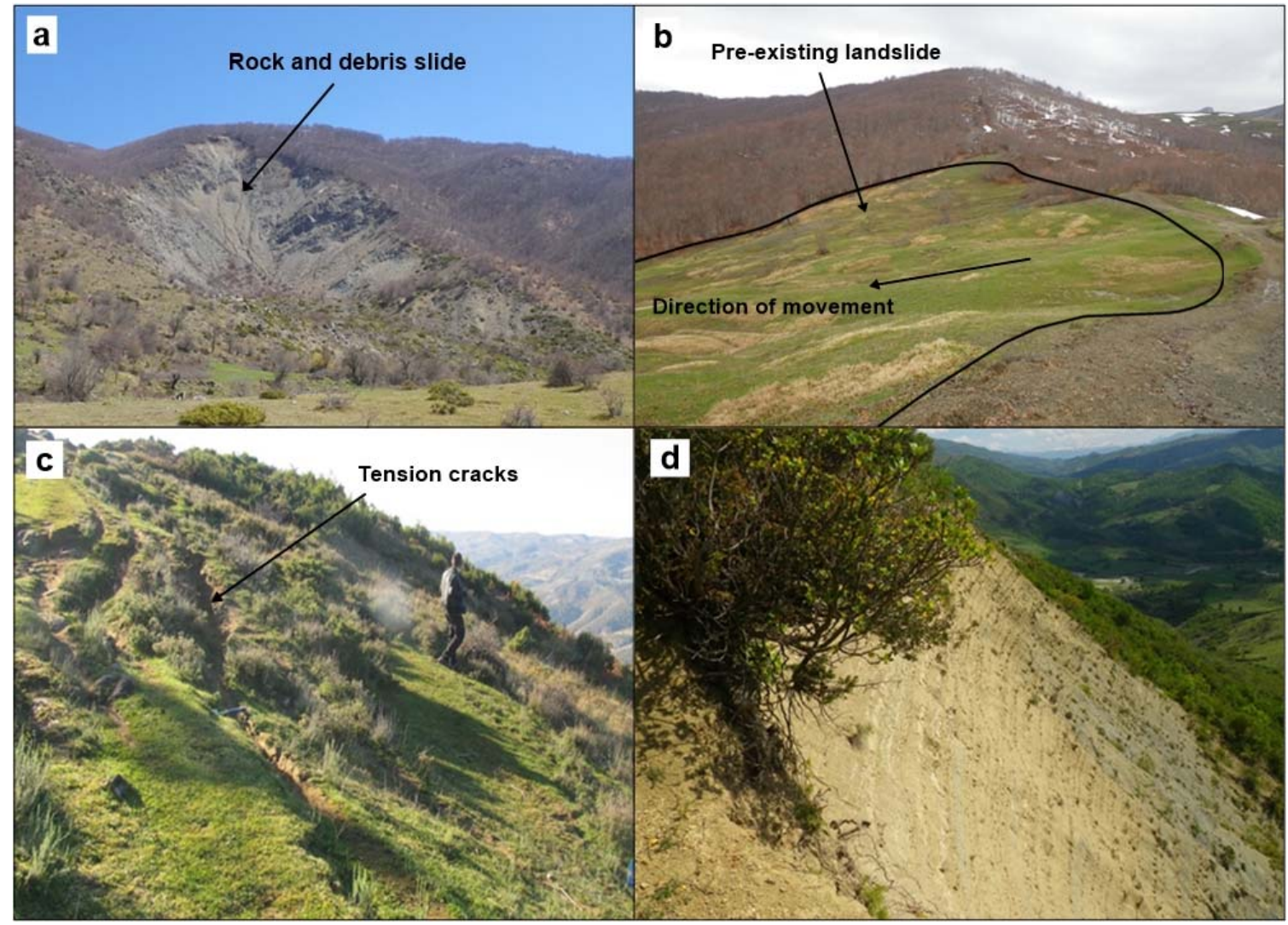

Figure 14. a: New failure (rock and debris slide) in the Potom valley (avoided by the re-route), b: Pre-existing landslide on the flank of a ridge, where a pipeline route runs, c: Tension cracks along a ridge flank, indicating potential for upslope retrogression of pre-existing landslides, $\mathbf{d}$ : Very steep landslide back scar extending to the ridge crest, with potential for further upslope retrogression. 
Table 1. Indicative landslide hazard assessment for some of the 82 identified landslides, including key assessment parameters and proposed actions (see Figures 12 and 13).

\begin{tabular}{|c|c|c|c|c|c|c|c|c|}
\hline Landslide & Activity $^{1}$ & Scale $^{2}$ & $\begin{array}{l}\text { Proximity (to) } \\
\text { (Distance) }^{3}\end{array}$ & $\begin{array}{c}\text { Slope } \\
\text { Steepness }\end{array}$ & $\begin{array}{l}\text { Ground } \\
\text { Quality }\end{array}$ & $\begin{array}{l}\text { Sliding } \\
\text { Depth }^{6}\end{array}$ & $\begin{array}{l}\text { Hazard } \\
\text { Class }\end{array}$ & Action \\
\hline ALS-1C & active & $\begin{array}{c}\text { small } \\
\left(1886 \mathrm{~m}^{2}\right)\end{array}$ & $\begin{array}{l}\text { proximate } \\
\text { (flank) } \\
(10 \mathrm{~m})\end{array}$ & gentle & Poor & shallow & low & $\begin{array}{l}\text { Avoid: Move the route } 15 \mathrm{~m} \text { to the NE } \\
\text { (discussed in the field) }\end{array}$ \\
\hline ALS-3B & active & $\begin{array}{c}\text { medium } \\
\left(19,188 \mathrm{~m}^{2}\right)\end{array}$ & $\begin{array}{l}\text { proximate } \\
(\text { crown }) \\
(7 \mathrm{~m})\end{array}$ & $\begin{array}{l}\text { moderately } \\
\text { steep }\end{array}$ & poor & medium & moderate & $\begin{array}{l}\text { Investigation-Remedial Measures } \\
\text { (not considered extensive and deep) }\end{array}$ \\
\hline ALS-7B & active & $\begin{array}{c}\text { small } \\
\left(6067 \mathrm{~m}^{2}\right)\end{array}$ & $\begin{array}{l}\text { distant (crown) } \\
(28 \mathrm{~m})\end{array}$ & gentle & poor & shallow & low & $\begin{array}{l}\text { Investigation-Remedial Measures } \\
\text { (not considered extensive and deep) }\end{array}$ \\
\hline ALS-10C & active & $\begin{array}{c}\text { small } \\
\left(746 \mathrm{~m}^{2}\right)\end{array}$ & $\begin{array}{l}\text { in contact } \\
(\text { crown }) \\
(2 \mathrm{~m})\end{array}$ & gentle & poor & shallow & moderate & $\begin{array}{l}\text { Investigation-Remedial Measures } \\
\text { (not considered extensive and deep) }\end{array}$ \\
\hline ALS-13B & active & $\begin{array}{l}\text { medium } \\
\left(31,684 \mathrm{~m}^{2}\right)\end{array}$ & $\begin{array}{c}\text { proximate } \\
\text { (crown) } \\
(23 \mathrm{~m})\end{array}$ & gentle & poor & shallow & moderate & $\begin{array}{c}\text { Investigation-Remedial Measures } \\
\text { (not considered extensive, approximately } 60 \mathrm{~m} \text { ) }\end{array}$ \\
\hline ALS-14AB & active & $\begin{array}{c}\text { large } \\
\left(90,259 \mathrm{~m}^{2}\right)\end{array}$ & $\begin{array}{l}\text { in contact } \\
\text { (crown) } \\
(2 \mathrm{~m})\end{array}$ & gentle & poor & medium & high & $\begin{array}{l}\text { Investigation-Remedial Measures } \\
\text { Isolate the pipeline from the sliding mass }\end{array}$ \\
\hline ALS-15C & active & $\begin{array}{c}\text { small } \\
\left(3493 \mathrm{~m}^{2}\right)\end{array}$ & $\begin{array}{l}\text { in contact } \\
\text { (crown) } \\
(2 \mathrm{~m})\end{array}$ & gentle & poor & shallow & moderate & $\begin{array}{l}\text { Isolate the pipeline from the sliding mass } \\
\text { (from the measures of the ALS-14AB) }\end{array}$ \\
\hline ALS-16B & active & $\begin{array}{l}\text { medium } \\
\left(39,230 \mathrm{~m}^{2}\right)\end{array}$ & $\begin{array}{l}\text { in contact (body) } \\
(0 \mathrm{~m})\end{array}$ & $\begin{array}{l}\text { moderately } \\
\text { steep }\end{array}$ & moderate & medium & moderate & Avoid: Keep the pipeline to the southern side \\
\hline ALS-17B & active & $\begin{array}{l}\text { medium } \\
\left(32,751 \mathrm{~m}^{2}\right)\end{array}$ & $\begin{array}{l}\text { distant (crown) } \\
(21 \mathrm{~m})\end{array}$ & gentle & moderate & medium & low & Avoid: Keep the pipeline to the NE \\
\hline ALS-21C & active & $\begin{array}{c}\text { small } \\
\left(8664 \mathrm{~m}^{2}\right)\end{array}$ & $\begin{array}{l}\text { distant (flank) } \\
\quad(74 \mathrm{~m})\end{array}$ & gentle & moderate & medium & low & Avoid \\
\hline ALS-22C & active & $\begin{array}{c}\text { small } \\
\left(2747 \mathrm{~m}^{2}\right)\end{array}$ & $\begin{array}{l}\text { distant (flank) } \\
\quad(36 \mathrm{~m})\end{array}$ & gentle & moderate & medium & low & Avoid \\
\hline ALS-45C & active & $\begin{array}{c}\text { small } \\
\left(820 \mathrm{~m}^{2}\right)\end{array}$ & $\begin{array}{l}\text { proximate } \\
\text { (crown) } \\
(6 \mathrm{~m})\end{array}$ & $\begin{array}{l}\text { moderately } \\
\text { steep }\end{array}$ & moderate & medium & moderate & $\begin{array}{l}\text { Investigation - Remedial Measures } \\
\text { (not considered extensive and deep) }\end{array}$ \\
\hline
\end{tabular}


Table 1. Cont.

\begin{tabular}{|c|c|c|c|c|c|c|c|c|}
\hline Landslide & Activity $^{1}$ & Scale $^{2}$ & $\begin{array}{l}\text { Proximity (to) }{ }^{3} \\
\text { (Distance) }^{\text {Distance }}\end{array}$ & $\begin{array}{c}\text { Slope } \\
\text { Steepness }\end{array}$ & $\begin{array}{l}\text { Ground } \\
\text { Quality }\end{array}$ & $\begin{array}{l}\text { Sliding } \\
\text { Depth } 6\end{array}$ & $\begin{array}{l}\text { Hazard } \\
\text { Class }\end{array}$ & Action \\
\hline ALS-47B & unknown & $\begin{array}{c}\text { large } \\
\left(220,536 \mathrm{~m}^{2}\right)\end{array}$ & $\begin{array}{l}\text { in contact } \\
(\text { crown }) \\
(3 \mathrm{~m})\end{array}$ & gentle & moderate & medium & high & $\begin{array}{l}\text { Investigation - Remedial Measures } \\
\text { (not considered extensive and deep) }\end{array}$ \\
\hline ALS-60B & active & $\begin{array}{c}\text { large } \\
\left(53,689 \mathrm{~m}^{2}\right)\end{array}$ & $\begin{array}{l}\text { proximate (toe) } \\
\qquad(12 \mathrm{~m})\end{array}$ & $\begin{array}{l}\text { moderately } \\
\text { steep }\end{array}$ & poor & medium & high & $\begin{array}{c}\text { Keep the pipeline below the sliding surface by } \\
\text { changing the excavation method (e.g., } \\
\text { microtunnelling) }\end{array}$ \\
\hline ALS-62A & unknown & $\begin{array}{c}\text { large } \\
\left(368,450 \mathrm{~m}^{2}\right)\end{array}$ & $\begin{array}{l}\text { distant (toe) } \\
\quad(185 \mathrm{~m})\end{array}$ & gentle & poor & medium & low & In an adequate distance from the pipeline \\
\hline ALS-65B & unknown & $\begin{array}{c}\text { large } \\
\left(381,025 \mathrm{~m}^{2}\right)\end{array}$ & $\begin{array}{l}\text { distant (body) } \\
\quad(80 \mathrm{~m})\end{array}$ & gentle & poor & medium & low & Avoid. A local rerouting was decided \\
\hline
\end{tabular}

NOTES

1. The activity status was assessed based on the presence of typical in situ evidence, such as fresh cracks, surface water ponds, unvegetated scarps, etc.

2. Surface area: Small: $\leq 10,000 \mathrm{~m}^{2}$, Medium: $10,000-50,000 \mathrm{~m}^{2}$, Large: $>50,000 \mathrm{~m}^{2}$

Proximity (to) (distance): In contact with: $\leq 5 \mathrm{~m}$, Proximate: $5-50 \mathrm{~m}$, Distant: Distance $>50 \mathrm{~m}$

Gentle: Slope angle $\leq 25^{\circ}$, Moderately Steep: $25^{\circ}<$ Slope angle $\leq 45^{\circ}$, Steep: Slope angle $>45^{\circ}$. These ranges are indicative and correspond to the steepness, under which the encountered rock mass types can potentially fail isotropically

5. Poor-Very Poor: GSI $\leq 20$, Moderate: $20<$ GSI $\leq 35$, Good $35<$ GSI $\leq 55$, Excellent: GSI $>55$. Excellent ground conditions were not recorded in the study area.

6. Sliding depth: Shallow: $\leq 5 \mathrm{~m}$, Medium: 5-15m, Deep: $>15 \mathrm{~m}$. 
These criteria were addressed by assigning threshold values to each one of the corresponding levels. It is, however, noted that these values were chosen on the basis of empirical judgment, as well as acquired experience. Regarding the activity status and the failure surface depth, where inclinometer readings were available the values were directly extracted; yet since such data was not available for most sites, the corresponding values were assigned either on the basis of geomorphological evidence or on the failure mechanism that appeared to control each landslide. For example, rotational slides were generally categorized as deep, whereas creeps, which typically occur within the weathering mantle of the rock mass, were categorized as shallow.

\section{Landslide Risk Assessment}

\subsection{Likelihood of Pipeline Rupture (Risk Levels)}

A qualitative 5-class likelihood scale has been used to rate the risk (i.e., chance of pipeline rupture) at each of the 82 examined landslide sites. These classes can be linked approximately to the frequency/probability columns used in standard risk matrices, using the expected initiating events as a guide (Table 2). These ranges provide a broad indication of the judged event probability and should not be viewed as implying a rigorous quantification of the likelihood of slope failure. It should be stressed that we have not undertaken a quantitative landslide risk assessment, and further differentiation of probability values was not possible at this stage on the basis of the available information.

Table 2. Indicative annual probability ranges associated with different risk-level classes used in this work (ranges allow estimated landslide risks to be employed on a standard risk matrix).

\begin{tabular}{|c|c|c|c|}
\hline Risk Level & $\begin{array}{c}\text { Indicative Risk } \\
\text { Condition (Pipeline } \\
\text { Rupture) }\end{array}$ & $\begin{array}{l}\text { 25-YEAR Project Life } \\
\text { Indicative Annual } \\
\text { Probability Range }\end{array}$ & Landslide Triggering Conditions \\
\hline $\mathrm{HIGH}$ & $\begin{array}{l}>10 \% \text { chance of } \\
\text { occurrence during } \\
\text { PROJECT }\end{array}$ & $\begin{array}{c}>0.004 \\
(>1 \text { in } 250)\end{array}$ & $\begin{array}{l}\text { Can occur in response to climatic } \\
\text { factors }\end{array}$ \\
\hline MEDIUM & $\begin{array}{l}1 \text { to } 10 \% \text { chance of } \\
\text { occurrence during } \\
\text { PROJECT }\end{array}$ & $\begin{array}{c}0.004 \text { to } 0.0004 \\
(1 \text { in } 250 \text { to } 1 \text { in } 2500)\end{array}$ & $\begin{array}{l}\text { Requires low-frequency strong } \\
\text { earthquake to cause event }\end{array}$ \\
\hline LOW & $\begin{array}{l}0.1 \text { to } 1 \% \text { chance of } \\
\text { occurrence during } \\
\text { PROJECT }\end{array}$ & $\begin{array}{c}0.0004 \text { to } 0.00004 \\
(1 \text { in } 2500 \text { to } 1 \text { in } 25,000)\end{array}$ & $\begin{array}{l}\text { Requires unlikely combination of } \\
\text { circumstances (e.g., a combination of } \\
\text { very-low-probability earthquake and } \\
\text { exceptional climatic conditions) }\end{array}$ \\
\hline NEGLIGIBLE & $\begin{array}{l}<0.1 \% \text { chance of } \\
\text { occurrence during } \\
\text { PROJECT }\end{array}$ & $\begin{array}{c}<0.00004 \\
(<1 \text { in } 25,000)\end{array}$ & $\begin{array}{l}\text { Only a very remote possibility that } \\
\text { the event could occur }\end{array}$ \\
\hline NONE & Not possible & 0 & $\mathrm{~N} / \mathrm{A}$ \\
\hline
\end{tabular}

\subsection{Risk Assessment Methodology}

As earlier discussed, the form, rate and duration of the possible landslide expected at each site are determined by several site factors, such as the slope conditions, the materials involved and the geological structure (e.g., rock mass quality and discontinuities). However, the sequence of events that leads to pipeline rupture can be complex and challenging to model, involving the occurrence of a triggering event (e.g., a moderate-to-strong earthquake or periods of heavy rainfall), a landslide event that extends upslope sufficiently far to impact the RoW and the resilience of the pipeline to this event.

As illustrated in Figure 15, there is significant uncertainty for this event sequence. For example, it is not known whether a strong earthquake will actually cause a major landslide at a particular site. If a landslide occurs, it may be confined to the slope face and not affect the ridge crest, or simply cause minor ground displacement on the ridge crest. Even if the landslide affects the RoW, it may be too small to cause rupture through the development of an unsupported span or simply not reach the 
pipeline. These uncertainties can be modelled conceptually by different branches of the event tree shown in Figure 15.

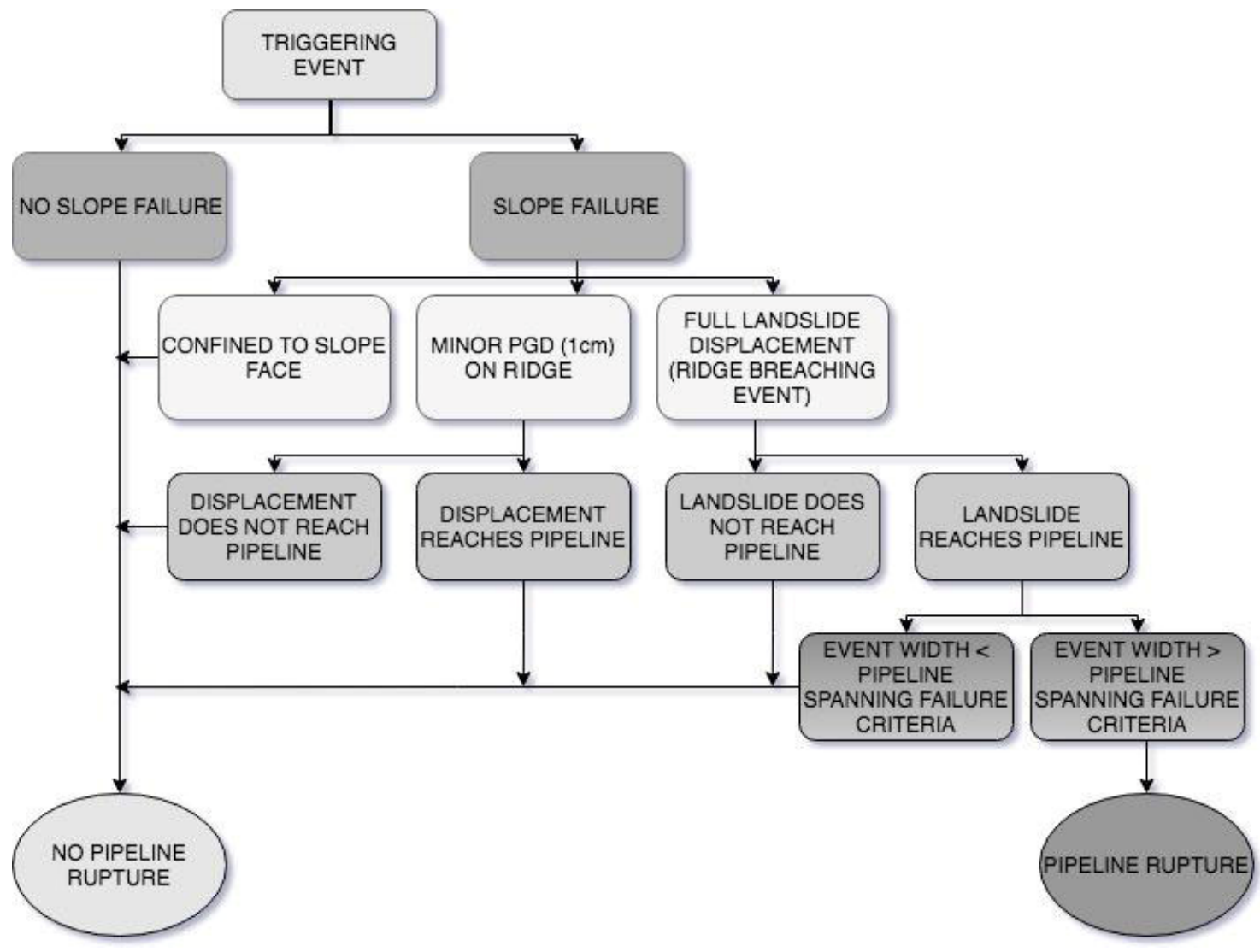

Figure 15. Event tree illustrating the event sequences involved in generating pipeline rupture considered for hazard assessment.

Figure 15 presents a simple logic tree risk model that incorporates all these key issues, leading to the "No" to "High" Risk classification of all the identified hotspots. The implemented risk assessment scheme was based on six evaluated parameters. Three parameters describe the potential impact of an event on the pipeline, namely the hazard potential: (i) Landslide area; (ii) Landslide depth, and (iii) Proximity to pipeline, while the other three are associated with the event likelihood (probability): (i) Landslide activity; (ii) Ground quality, and (iii) Slope. These parameters were each assigned a value from 1 to 3 and a weight factor, depending on their significance for the assessment (Table 3).

Table 3. Risk assessment scheme, including the six main parameter values and their relative weighting factors.

\begin{tabular}{|c|c|c|c|c|c|c|}
\hline \multirow[b]{2}{*}{ Parameter } & \multicolumn{3}{|c|}{$\begin{array}{c}\text { Potential Impact on the Pipeline upon } \\
\text { Activation }\end{array}$} & \multicolumn{3}{|c|}{ Likelihood of Activation } \\
\hline & $\begin{array}{c}\text { Landslide } \\
\text { area }\end{array}$ & $\begin{array}{l}\text { Landslide } \\
\text { depth }\end{array}$ & $\begin{array}{c}\text { Proximity to } \\
\text { pipeline }\end{array}$ & $\begin{array}{l}\text { Landslide } \\
\text { activity }\end{array}$ & $\begin{array}{l}\text { Ground } \\
\text { quality }\end{array}$ & Slope \\
\hline Weight factor & $15 \%$ & $25 \%$ & $60 \%$ & $50 \%$ & $25 \%$ & $25 \%$ \\
\hline Value $=3$ & large & deep & in contact with & active & poor & very steep \\
\hline Value $=2$ & medium & medium & close to & $\begin{array}{c}\text { of unknown } \\
\text { activity }\end{array}$ & moderate & $\begin{array}{l}\text { moderately } \\
\text { steep }\end{array}$ \\
\hline Value $=1$ & small & shallow & distant from & inactive & good & gentle \\
\hline
\end{tabular}

In practice, the chance of pipeline rupture is not the same as the chance of a triggering event, as there are other possible outcomes that can follow and that do not lead to rupture. This event sequence 
provides the framework for estimating the chance of pipeline rupture at each of the 82 landslide sites in Albania (Figure 16). For the risk assessment, judgements were made for each site regarding several key issues:

- Could a credible landslide event reach the pipeline? (Figure 16) Answering this question requires a judgement to be made about the size and intensity of the "expected landslide event" that could occur at a particular site, based on the current knowledge of the geological and geomorphological conditions. Clearly, the farther the landslide is from the route, the larger the event would have to be, while in many cases it was not considered credible for a landslide to reach the pipeline RoW.

- Given that the expected landslide has reached the pipeline, could the landslide cause a pipeline rupture event? (Figure 16) This involves a judgement about the potential for the landslide to generate conditions that exceed the simple displacement or spanning failure criteria. At several sites, the expected landslide was judged to be too small or shallow to cause pipeline rupture. However, at sites where several major landslides are found that could impact the pipeline, the rupture is considered as very probable.

- Given that a pipeline rupture event is possible, could the expected landslide be initiated under static conditions (i.e., triggered by climatic factors such as heavy rainfall or rapid snow melt)? If the site is stable under static conditions, could the expected landslide be initiated by a low-frequency strong earthquake (non-static conditions? (Figure 16) This judgement was based on the current knowledge of the geological and geomorphological conditions at a particular site, supported by the findings of static-case slope stability analyses at seven indicative sites. It is noted that for the static and non-static (seismic) stability analyses, landslides were assumed to be triggered in those cases where the Factor of Safety was less than 1.0, and, because of uncertainties about the ground conditions and groundwater levels, where the Factor of Safety was marginally above 1.

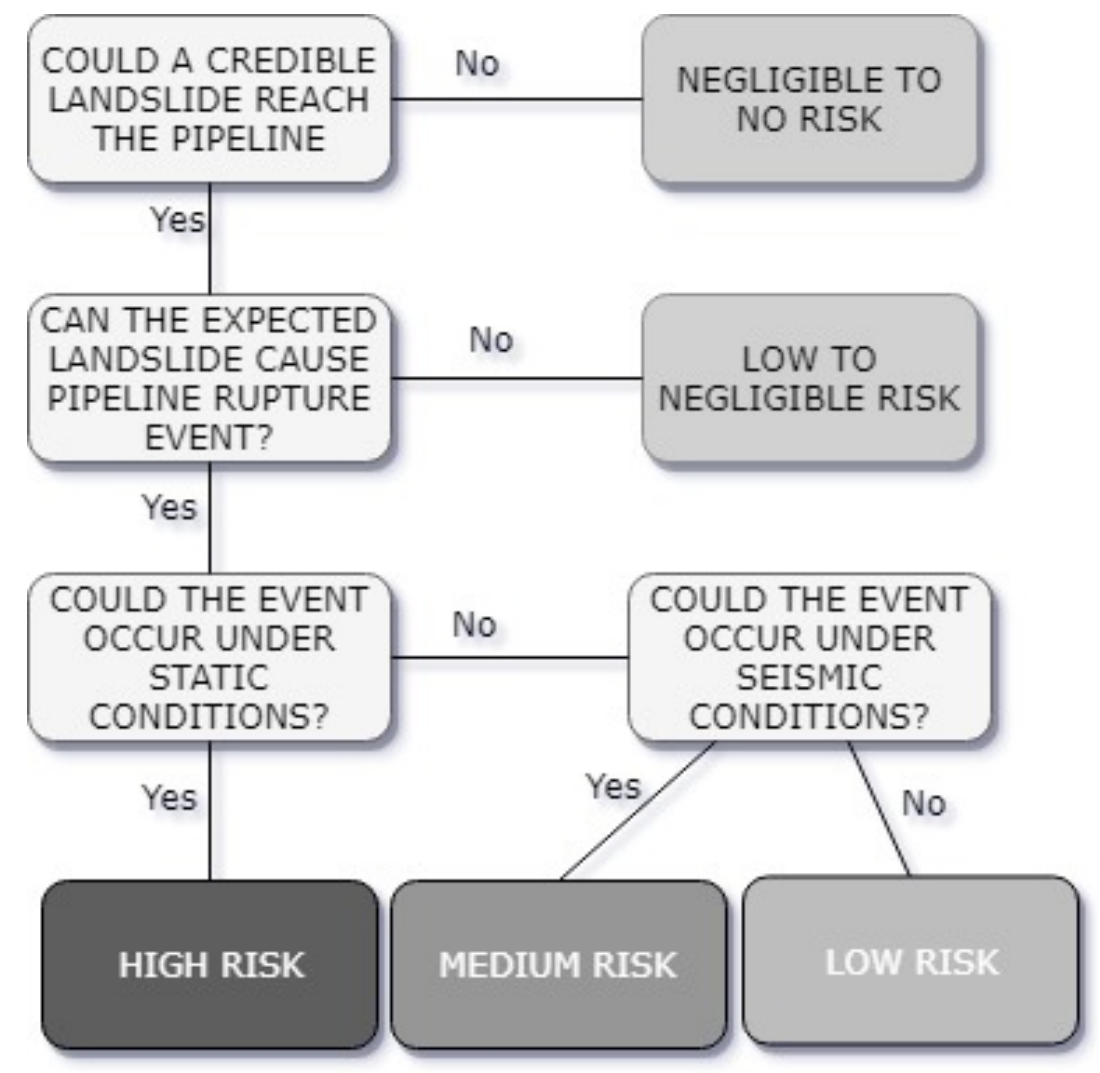

Figure 16. Landslide risk model employed developed in the present work. 
Vulnerability is a difficult expression to represent quantitatively as part of a landslide risk analysis because it cannot be measured objectively. Vulnerability typically depends on both the characteristics of the element at risk and the landslide intensity. Several researchers have proposed various approaches to assess landslide vulnerability [23]. For our case, vulnerability was not evaluated in detail but was mainly assessed through the expected landslide intensity. The threat to the pipeline integrity was mainly based on the area, the depth and the proximity of the landslide. Our assessment was also based on pipeline verification analyses that have been indicatively performed for seven sites and showed a pipeline spanning failure criteria threshold of $30 \mathrm{~m}$. It is noted though that this limit corresponds to the most conservative case of mass movements and larger values were computed in several cases. The risk assessment breakdown procedure is presented in Table 4.

Table 4. Risk assessment estimation scheme adopted in the present work.

\begin{tabular}{|c|c|c|c|c|}
\hline $\begin{array}{l}\text { Likelihood of } \\
\text { Activation } \\
\text { Assessment }\end{array}$ & $\begin{array}{l}\text { Potential Impact on the } \\
\text { Pipeline upon } \\
\text { Activation Assessment }\end{array}$ & $\begin{array}{l}\text { Value Limits } \\
\text { (Lowest to } \\
\text { Highest Possible) }\end{array}$ & Risk Analysis & Risk Assessment \\
\hline low likelihood & low impact & $1.00-1.66$ & $\begin{array}{l}\text { low likelihood/ } \\
\text { low impact }\end{array}$ & low \\
\hline $\begin{array}{l}\text { moderate } \\
\text { likelihood }\end{array}$ & moderate impact & $1.66-2.33$ & $\begin{array}{l}\text { low likelihood/ } \\
\text { moderate impact }\end{array}$ & moderate \\
\hline \multirow[t]{7}{*}{ high likelihood } & high impact & $2.33-3.00$ & $\begin{array}{l}\text { low likelihood/ } \\
\text { high impact }\end{array}$ & high \\
\hline & & & $\begin{array}{c}\text { moderate likelihood/ } \\
\text { low impact }\end{array}$ & low \\
\hline & & & $\begin{array}{l}\text { moderate likelihood/ } \\
\text { moderate impact }\end{array}$ & moderate \\
\hline & & & $\begin{array}{c}\text { moderate likelihood/ } \\
\text { high impact }\end{array}$ & high \\
\hline & & & $\begin{array}{l}\text { high likelihood/ } \\
\text { low impact }\end{array}$ & low \\
\hline & & & $\begin{array}{l}\text { high likelihood/ } \\
\text { moderate impact }\end{array}$ & high \\
\hline & & & $\begin{array}{l}\text { high likelihood/ } \\
\text { high impact }\end{array}$ & high \\
\hline
\end{tabular}

It should be noted that the assessed risk levels for each site do not consider the impact of mitigation measures. In several cases, the risk could be significantly reduced through implementation of such measures, such as minor adjustment to the route (to increase the setback distance from the pre-existing landslide head), the construction of structures to isolate the pipeline from the effects of future landsliding (e.g., pile walls) or to reduce the likelihood of future damaging ground movements (e.g., geotechnical slope drainage).

\subsection{Risk Assessment Results}

An assessment of the risk level for the pipeline due to potential landslides has been performed along the whole examined TAP route (Table 5), namely the 64-km-long section between the Panarit ridge and Polican (72 to $136 \mathrm{~km}$ ), which includes the bulk of the mountainous region across Albania. The landslide risk profile for the route was dominated by the numerous landslide sites identified between 72 and 90 km, where nine High Risk and 12 Medium Risk sites are found on the slopes adjacent to the RoW alignment (Figures 17 and 18). Medium risk sites mainly occurred on the western flank of the ridge crest at $\mathrm{km} 98$ and $\mathrm{km} \mathrm{114}$, as well as on the very steep ridge flanks at $130 \mathrm{~km}$. 
Table 5. Indicative landslide risk assessment for some of the 82 identified landslides (see Figures 12, 13, 17 and 18).

\begin{tabular}{|c|c|c|c|c|c|c|c|c|c|c|c|c|c|c|c|c|c|c|c|}
\hline \multirow{3}{*}{$\begin{array}{l}\text { Landslide } \\
\text { ALS-1C }\end{array}$} & \multicolumn{6}{|c|}{$\begin{array}{l}\text { Parameters Affecting Expected Damage to Pipeline if } \\
\text { Landslide is Activated (Potential Impact on the } \\
\text { Pipeline upon Activation, Values } 1 \text { to } 3 \text { ) }\end{array}$} & \multirow{3}{*}{$\begin{array}{c}\begin{array}{c}\text { Potential } \\
\text { Impact }\end{array} \\
\text { low }\end{array}$} & \multirow{3}{*}{$\begin{array}{c}\begin{array}{c}\text { Impact } \\
\text { Value }\end{array} \\
1.6\end{array}$} & \multicolumn{6}{|c|}{$\begin{array}{l}\text { Parameters Affecting Possibility of Landslide Activation } \\
\text { (Likelihood of Activation, Values } 1 \text { to 3) }\end{array}$} & \multirow{3}{*}{$\begin{array}{c}\begin{array}{c}\text { Likelihood of } \\
\text { Activation }\end{array} \\
\text { high }\end{array}$} & \multirow{3}{*}{$\begin{array}{c}\begin{array}{c}\text { Likelihood } \\
\text { Value }\end{array} \\
2.5\end{array}$} & \multirow{3}{*}{$\begin{array}{c}\text { Risk } \\
\text { Value } \\
4.00 \\
\end{array}$} & \multirow{3}{*}{$\begin{array}{c}\text { Risk Analysis } \\
\text { high likelihood-low } \\
\text { impact }\end{array}$} & \multirow{3}{*}{$\begin{array}{c}\begin{array}{c}\text { Risk } \\
\text { Assessment }\end{array} \\
\text { low }\end{array}$} \\
\hline & \multicolumn{2}{|c|}{$\begin{array}{c}\text { Landslide } \\
\text { Area }\end{array}$} & \multicolumn{2}{|c|}{$\begin{array}{l}\text { Landslide } \\
\text { Depth }\end{array}$} & \multicolumn{2}{|c|}{$\begin{array}{c}\text { Proximity to } \\
\text { Pipeline }\end{array}$} & & & \multicolumn{2}{|l|}{$\begin{array}{l}\text { Landslide } \\
\text { Activity }\end{array}$} & \multicolumn{2}{|c|}{$\begin{array}{l}\text { Ground } \\
\text { Quality }\end{array}$} & \multicolumn{2}{|l|}{ Slope Angle } & & & & & \\
\hline & small & 1 & shallow & 1 & close to & 2 & & & active & 3 & poor & 3 & gentle & 1 & & & & & \\
\hline ALS-3B & medium & 2 & medium & 2 & close to & 2 & moderate & 2 & $\begin{array}{l}\text { of unknown } \\
\text { activity }\end{array}$ & 2 & poor & 3 & $\begin{array}{l}\text { moderately } \\
\text { steep }\end{array}$ & 2 & moderate & 2.25 & 4.50 & $\begin{array}{l}\text { moderate likelihood- } \\
\text { moderate impact }\end{array}$ & moderate \\
\hline ALS-7B & small & 1 & shallow & 1 & distant from & 1 & low & 1 & active & 3 & poor & 3 & gentle & 1 & high & 2.5 & 2.50 & $\begin{array}{l}\text { high likelihood-low } \\
\text { impact }\end{array}$ & low \\
\hline ALS-10C & small & 1 & shallow & 1 & in contact with & 3 & moderate & 2.2 & active & 3 & poor & 3 & gentle & 1 & high & 2.5 & 5.50 & $\begin{array}{l}\text { high likelihood- } \\
\text { moderate impact }\end{array}$ & high \\
\hline ALS-13B & medium & 2 & shallow & 1 & close to & 2 & moderate & 1.75 & active & 3 & poor & 3 & gentle & 1 & high & 2.5 & 4.38 & $\begin{array}{l}\text { high likelihood- } \\
\text { moderate impact }\end{array}$ & high \\
\hline ALS-14AB & large & 3 & medium & 2 & in contact with & 3 & high & 2.75 & active & 3 & poor & 3 & gentle & 1 & high & 2.5 & 6.88 & $\begin{array}{l}\text { high likelihood- low } \\
\text { impact }\end{array}$ & high \\
\hline ALS-15C & small & 1 & shallow & 1 & in contact with & 3 & moderate & 2.2 & $\begin{array}{l}\text { of unknown } \\
\text { activity }\end{array}$ & 2 & poor & 3 & gentle & 1 & moderate & 2 & 4.40 & $\begin{array}{l}\text { moderate likelihood- } \\
\text { moderate impact }\end{array}$ & moderate \\
\hline ALS-16B & medium & 0 & medium & 2 & in contact with & 3 & moderate & 2.3 & $\begin{array}{l}\text { of unknown } \\
\text { activity }\end{array}$ & 2 & moderate & 2 & $\begin{array}{l}\text { moderately } \\
\text { steep }\end{array}$ & 2 & moderate & 2 & 4.60 & $\begin{array}{l}\text { moderate likelihood- } \\
\text { moderate impact }\end{array}$ & moderate \\
\hline ALS-17B & medium & 2 & medium & 2 & distant from & 1 & low & 1.4 & active & 3 & moderate & 2 & gentle & 1 & moderate & 2.25 & 3.15 & $\begin{array}{l}\text { moderate likelihood- } \\
\text { low impact }\end{array}$ & low \\
\hline ALS-21C & small & 1 & medium & 2 & distant from & 1 & low & 1.25 & active & 3 & moderate & 2 & gentle & 1 & moderate & 2.25 & 2.81 & $\begin{array}{l}\text { moderate likelihood- } \\
\text { low impact }\end{array}$ & low \\
\hline ALS-22C & small & 1 & medium & 2 & distant from & 1 & low & 1.25 & active & 3 & moderate & 2 & gentle & 1 & moderate & 2.25 & 2.81 & $\begin{array}{l}\text { moderate likelihood- } \\
\text { low impact }\end{array}$ & low \\
\hline ALS- $45 \mathrm{C}$ & small & 1 & medium & 2 & close to & 2 & moderate & 1.85 & $\begin{array}{l}\text { of unknown } \\
\text { activity }\end{array}$ & 2 & moderate & 2 & $\begin{array}{l}\text { moderately } \\
\text { steep }\end{array}$ & 2 & moderate & 2 & 3.70 & $\begin{array}{l}\text { moderate likelihood- } \\
\text { moderate impact }\end{array}$ & moderate \\
\hline ALS-47B & large & 3 & medium & 2 & in contact with & 3 & high & 2.75 & $\begin{array}{l}\text { of unknown } \\
\text { activity }\end{array}$ & 2 & moderate & 2 & gentle & 1 & moderate & 1.75 & 4.81 & $\begin{array}{l}\text { moderate likelihood- } \\
\text { high impact }\end{array}$ & high \\
\hline ALS-60B & large & 3 & deep & 3 & close to & 2 & high & 2.4 & active & 3 & poor & 3 & $\begin{array}{l}\text { moderately } \\
\text { steep }\end{array}$ & 2 & high & 2.75 & 6.6 & $\begin{array}{l}\text { high likelihood-high } \\
\text { impact }\end{array}$ & high \\
\hline ALS-62A & large & 3 & medium & 2 & distant from & 1 & low & 1.55 & $\begin{array}{l}\text { of unknown } \\
\text { activity }\end{array}$ & 2 & poor & 3 & gentle & 1 & moderate & 2 & 3.10 & $\begin{array}{l}\text { moderate likelihood- } \\
\text { low impact }\end{array}$ & low \\
\hline ALS-65B & large & 3 & medium & 2 & distant from & 1 & low & 1.55 & $\begin{array}{l}\text { of unknown } \\
\text { activity }\end{array}$ & 2 & poor & 3 & gentle & 1 & moderate & 2 & 3.10 & $\begin{array}{l}\text { moderate likelihood- } \\
\text { low impact }\end{array}$ & low \\
\hline
\end{tabular}




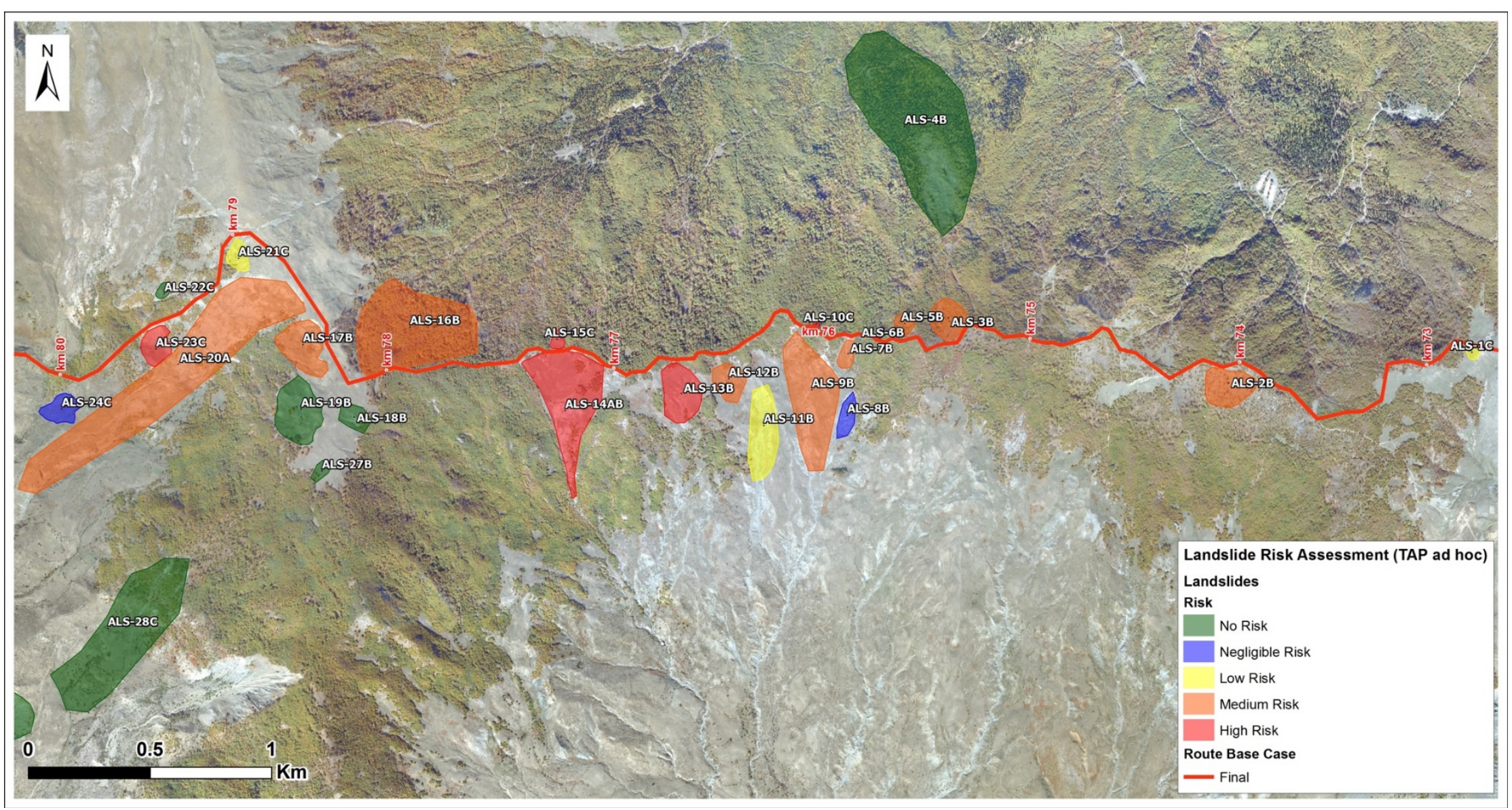

Figure 17. Landslide risk assessment results for the pipeline route from approximately 73 to $80 \mathrm{~km}$ (area north of Panarit village). The later presented example of landslide ALS-14AB is shown at the centre-left part of the section $(77 \mathrm{~km})$. 


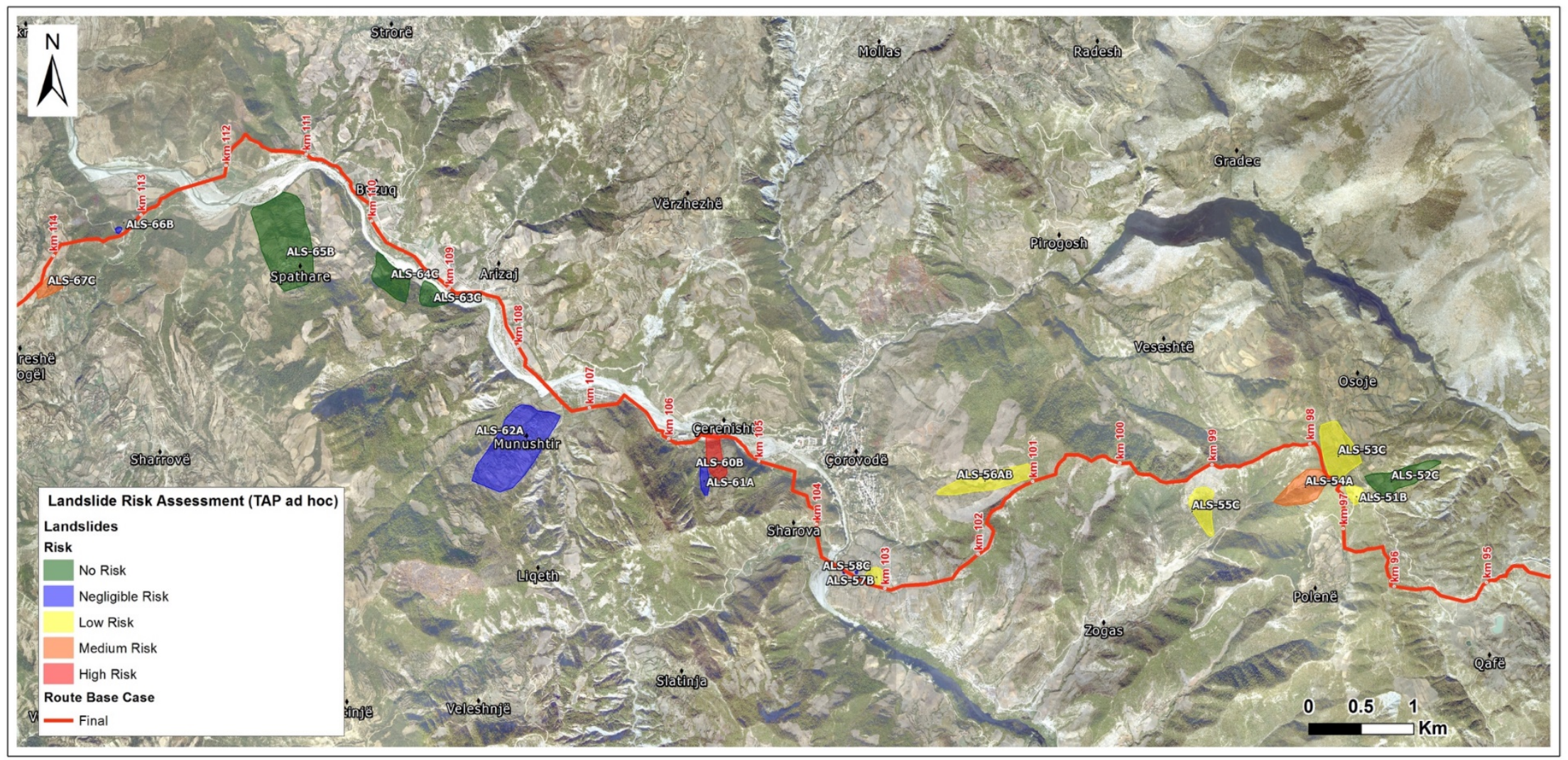

Figure 18. Landslide risk assessment results for the pipeline route from approximately 95 to $114 \mathrm{~km}$. The later presented example of landslide ALS-60B is shown at the central part of the map (105-106 km). 
Following this risk assessment, two large re-routings were considered. For the section between 77.5 and $90 \mathrm{~km}$, a re-routing that avoids significant unstable areas of the base case route was selected, as the pipeline generally runs along stable ridges. However, some unstable areas are could still be found parallel and perpendicular to these ridges. In some cases, further investigation was required to identify the site-specific geotechnical conditions and the probable remedial measures. For the section between 122 and $130 \mathrm{~km}$, a re-routing that avoids four (4) active unstable areas of the base case route was selected. For the remaining sections, where landslides cannot be avoided, crossing can be acceptable with remedial measures, after detailed geotechnical investigation and analysis. A typical case, for which re-routing was not feasible and where the RoW was located along the foot of a large active landslide (ALS-60B), the hazard was avoided by microtunnelling below the sliding mass.

\subsection{Risk Assessment Examples}

In the following, we present two (2) typical examples of the landslide assessment procedure. The location of both landslides is presented in Figures 17 and 18.

\subsubsection{Landslide ALS-14AB}

Landslide ALS- $14 \mathrm{AB}$ is a landslide approximately located at $77 \mathrm{~km}$ of the TAP route (Figures 13 and 17). It is a large (approx. 90,000 $\mathrm{m}^{2}$ ), medium depth landslide which is in contact with the pipeline (Figure 19). It is an active, translational landslide of poor ground quality (flysch type IX, Figure 8). The slope of the landslide is gentle. Evidence of activity has been identified on the surface in the form of fresh cracks and creeping evidence.

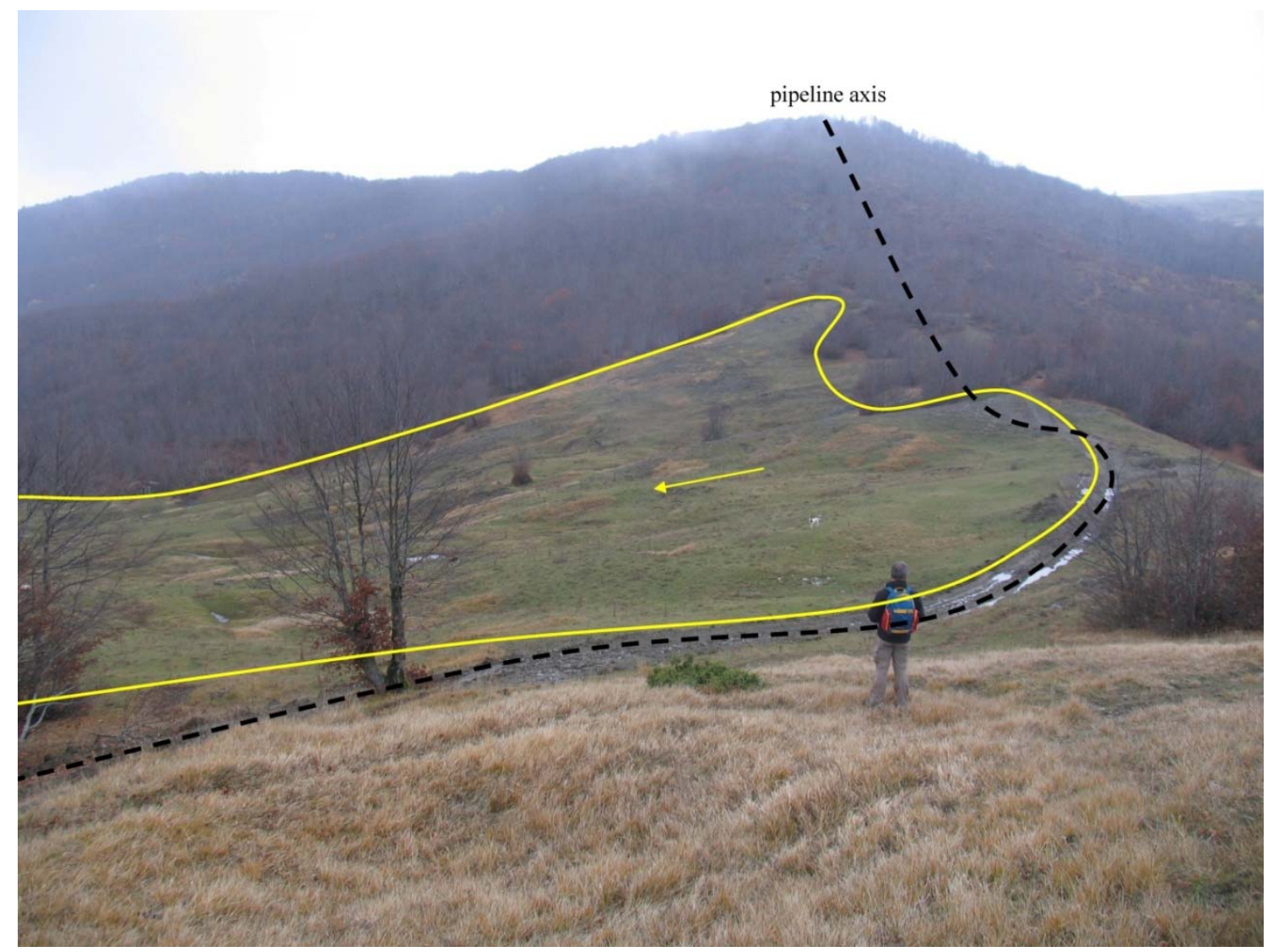

Figure 19. View of the slope at the location of ALS-14AB (Figures 9 and 13). The yellow line indicates the landslide boundaries (arrow pointing towards sliding direction), whereas the black line represents the position of the TAP pipeline axis. 
The main hazard posed by this landslide is the reactivation of the sheared ground, resulting in loss of ridge crest and subsequent pipeline rupture.

The landslide was evaluated in terms of risk as follows (Table 5):

(A) Parameters affecting expected damage to the pipeline, if the landslide is activated.

- Landslide area: Large, absolute value 3, weighted value $3 \times 15 \%=0.45$

- Landslide depth: Medium, absolute value 2, weighted value $2 \times 25 \%=0.50$

- Proximity to pipeline: In contact with pipeline, absolute value 3 , weighted value $3 \times 60 \%=1.8$

Total impact value: 2.75-Impact assessment: High

(B) Parameters affecting possibility of landslide activation.

- Landslide activity: Active, absolute value 3, weighted value $3 \times 50 \%=1.5$

- Ground quality: Poor, absolute value 3, weighted value $3 \times 25 \%=0.75$

- Slope angle: Gentle, absolute value 1 , weighted value $1 \times 25 \%=0.25$

Likelihood value: 2.5-Likelihood assessment: High

As such, the landslide was assigned a risk value of 6.88 (High impact—High likelihood) and classified as a high risk area.

\subsubsection{Landslide ALS-60B}

Landslide ALS-60B is located roughly at the $105 \mathrm{~km}$ mark of the TAP route (Figure 18), above the bed of the Osumi River. It is a large (approx. $54,000 \mathrm{~m}^{2}$ ) and deep landslide, and it is in very close proximity to the pipeline. It is an active landslide with moderate steepness $\left(25^{\circ}<\right.$ Slope angle $\left.\leq 45^{\circ}\right)$ of poor ground quality, with the crest of the landslide almost reaching the top of the slope. From the morphological indications of the landslide crown, which is arch-shaped (Figure 20), the presence of fresh recent transverse cracks (Figure 21) and the back-tilt of the main body (and smaller ones) we assigned a circular failure surface (rotational landslide). Smaller slides were present within the whole sliding mass, a feature typically expected for such a large landslide.

The landslide was evaluated in terms of risk as follows (Table 5):

(C) Parameters affecting expected damage to the pipeline, if the landslide is activated.

- Landslide area: Large, absolute value 3 , weighted value $3 \times 15 \%=0.45$

- Landslide depth: Deep, absolute value 3, weighted value $3 \times 25 \%=0.75$

- Proximity to pipeline: Close to pipeline, absolute value 2 , weighted value $2 \times 60 \%=1.2$

Impact value: 2.4-Impact assessment: High 


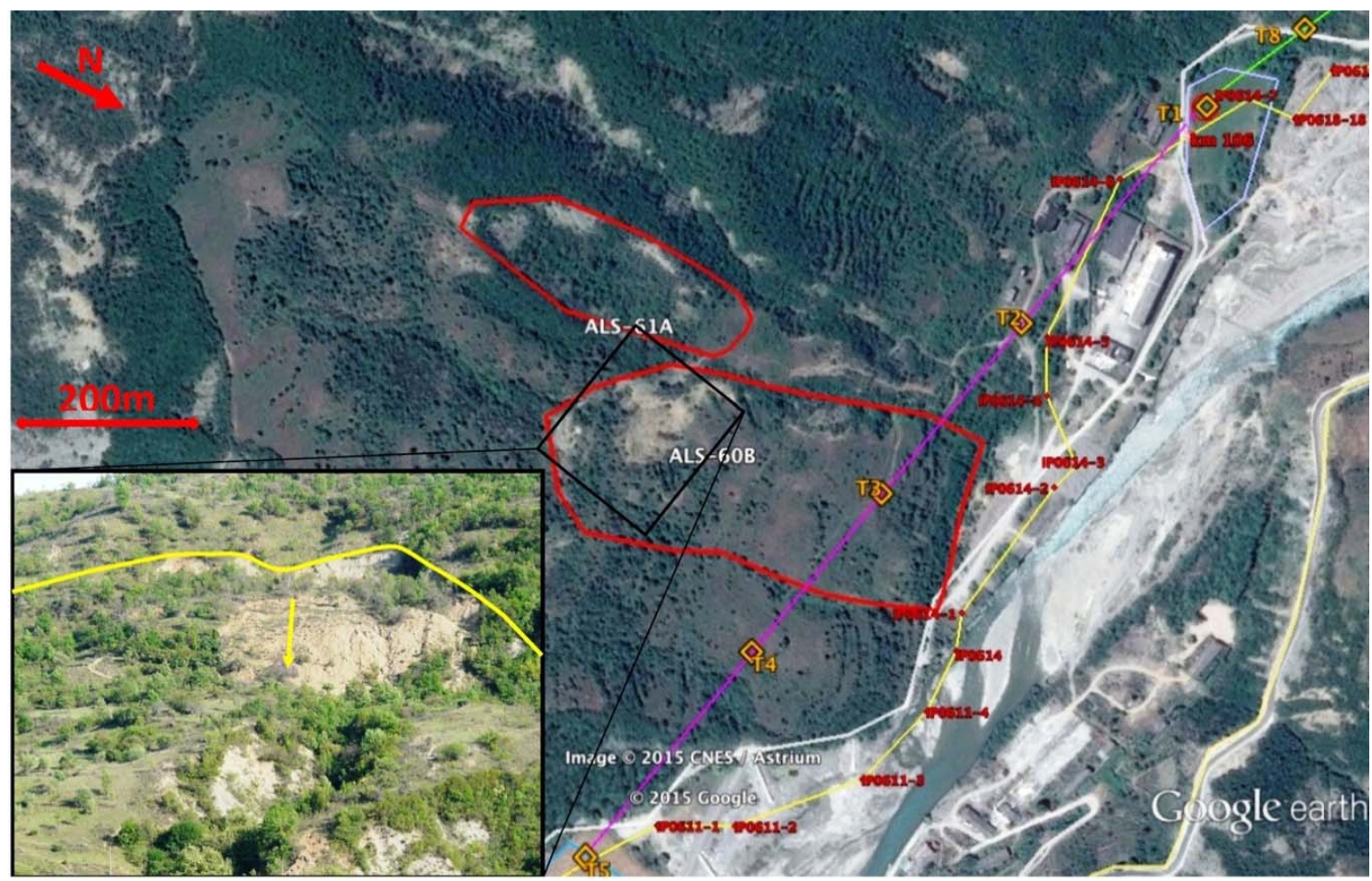

Figure 20. Initially proposed natural gas pipeline route (yellow line) relative to the active landslides ALS-60B (Figure 18) and ALS-61A, and proposed microtunnel (pink axis) solution designed to bypass beneath them, in Corovode area (Albania). The crest of landslide ALS-60B is shown in the inset picture.

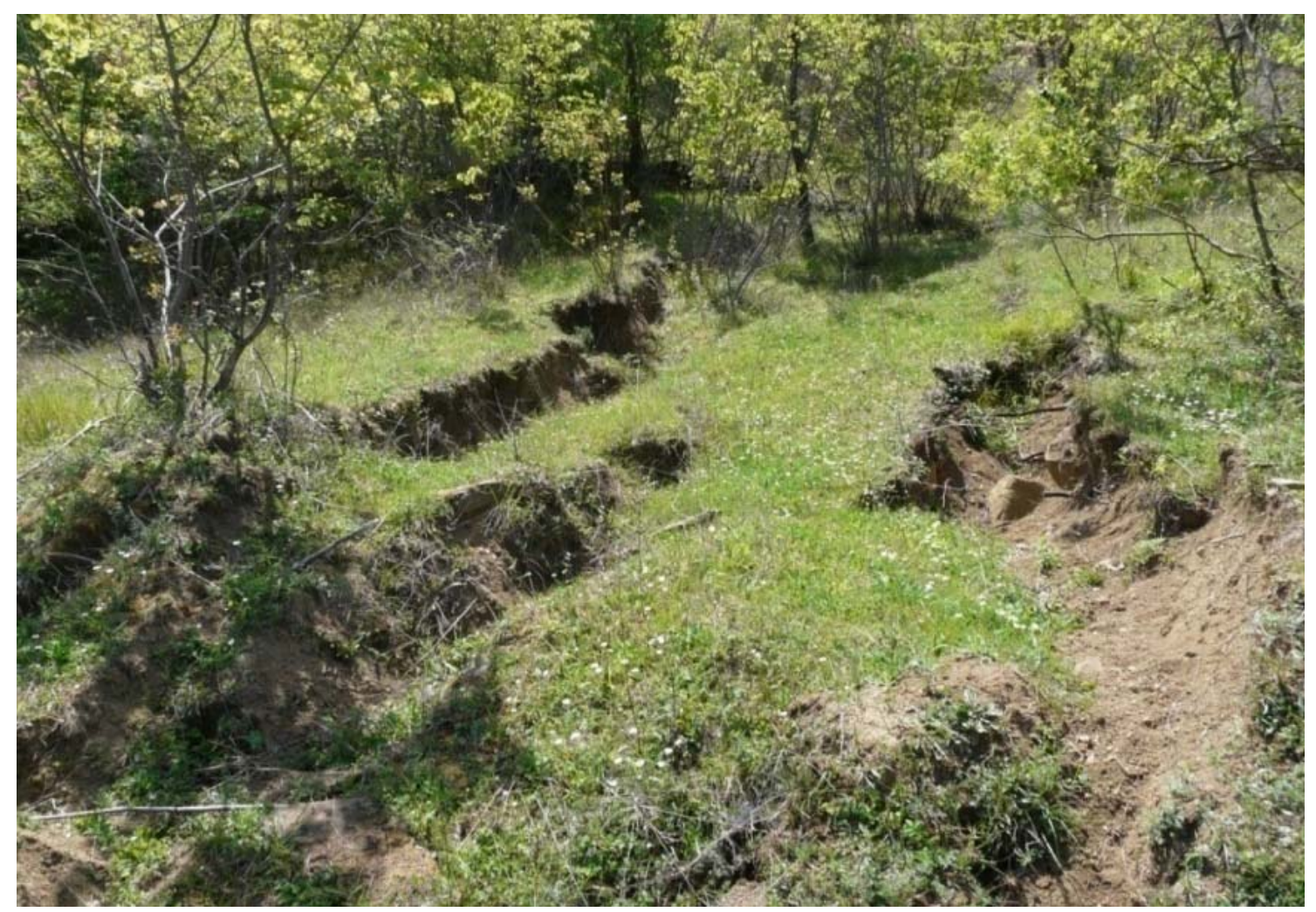

Figure 21. The activity of ALS-60B is manifested by large horizontal and vertical displacements (here some recent tensional cracks) within its mass. 
(D) Parameters affecting possibility of landslide activation.

- Landslide activity: Active, absolute value 3, weighted value $3 \times 50 \%=1.5$

- Ground quality: Poor, absolute value 3, weighted value $3 \times 25 \%=0.75$

- $\quad$ Slope angle: Moderately steep, absolute value 2 , weighted value $2 \times 25 \%=0.5$

Likelihood value: 2.75-Likelihood assessment: High

As such, the landslide was assigned a risk value of 6.6 (high impact-high likelihood) and classified as a high risk area. The identification of this landslide and the associated high-risk value resulted in the proposal for avoidance by means of microtunnelling below its sliding surface (Figure 16).

\section{Discussion}

Though, analytical methods may be preferred over qualitative methods, the presented assessment can be of interest to practitioners and geohazard consultants working with similar pipeline projects, as it presents a realistic and reasonable expert-based decision tree approach to grade landslides into different classes of risk, especially when tight schedules and lack of detailed geotechnical/geological information (something typical for extended linear lifelines, such as pipelines) do not allow a more detailed and quantitative assessment. As a result, it is important to be realistic about the precision and reliability of the assessed levels of risk at the various sites. The results provide a "high level" indication of how landslide risk is expected to vary through the mountain terrain in Albania and can be used to identify "hot spots" along the route where risk reduction measures could be prioritised. However, they are not a substitute for more detailed site evaluation that would be required to support the design and construction of mitigation measures at the critical slopes according to EN1997 and EN1998.

It is evident from the adopted approach that significant time and effort must be allocated towards a geo-engineering hazard and risk assessment before the finalization of the pipeline route. Regarding landslide activity and delineation, the geohazard expert's information must be supplemented by images from remote sensing technologies (e.g., various SAR techniques, LiDAR), extensive fieldwork along the pipeline route, as well as site investigation information on ground quality and groundwater pressure. This was not possible in this particular case, as the tight time schedule did not allow to acquire this level of additional information and execute an analytical risk assessment.

\section{Conclusions}

Landsliding is a major factor in route selection in the mountain regions of Albania along the Trans-Adriatic (TAP) pipeline. An assessment of the risk level for the pipeline due to potential landslides route has been undertaken, based on a critical review of the landslide and slope stability information that was available at the time for each of the 82 landslide sites that were identified along the route. The determined level of landslide risk is the inevitable consequence of TAP routing through mountainous terrain, exposed to high seismicity, intense rainfall and snow melt.

In line with international best practice, landslide features were identified and avoided by routing along ridge crests and spurs, and minimizing the exposure to potentially unstable, steep side slopes. However, due to the nature of the rugged terrain, the route passes in close proximity $(<50 \mathrm{~m})$ to known landslides on the ridge flanks and slopes that are believed to have the potential to fail at some point in the future. As a result, it has not been possible to eliminate the exposure to landslide risks. However, a possibility that new landslides could develop under static and/or seismic conditions is still present, especially on the steep ridge flanks between 77 and $90 \mathrm{~km}$ of the TAP route (Figure 8). Unforeseen landslide problems could still arise during the construction and operations phases of the project.

The estimated risk associated with the 82 landslide sites identified along the route represents an outcome from a "high-level" assessment performed in a workshop, comprising the suggestions and viewpoints of several geohazard experts of different institutes and companies involved in this project, regarding the exposure to "pre-existing" landslide sites. The risk profile is expected to be 
dominated by upslope expansion of existing landslides, resulting in loss of ridge crest and pipeline rupture. A qualitative 5-class likelihood scale has been used to rate the risk (i.e., chance of pipeline rupture) at each of the 82 sites. As a result of this procedure, ten (10) landslides were characterised as "High Risk", fifteen (15) as "Medium Risk" and nineteen (19) as "Low Risk", with the remaining ones were characterised as "None" or of "Negligible" risk.

Author Contributions: V.M.: Writing—original draft, Writing—review and editing, Methodology, Software; G.S.: Writing—original draft, Writing—review, Methodology; C.P.: Project administration, Writing-review.

Funding: E.ON Technologies GmbH (currently Uniper GmbH) S.A.

Acknowledgments: We would like to acknowledge E.ON Technologies GmbH (currently Uniper GmbH) S.A. for funding the presented work and, in particular, E. Schmidt, T. Cubaleski and A. Diendorfer for their constructive cooperation. This work was partly inspired by Mark Lee, whom we would like to thank for his insight and advice in developing the adopted hazard assessment approach. We would also like to thank K. Xanthopoulou, for her assistance in editing some of the figures and G. Papathanassiou and T. Stimaratzis for their contribution to field work.

Conflicts of Interest: The authors declare no conflict of interest.

\section{References}

1. Nyman, D.; Lee, E.M.; Audibert, J.M. Mitigating geohazards for international pipeline projects: Challenges and lessons learned. In Proceedings of the IPC 2008: 7th International Pipeline Conference, Calgary, AB, Canada, 29 September-3 October 2008; pp. 639-948.

2. Savigny, K.W.; Porter, M.; Leir, M. Geohazard risk management for the onshore pipeline industry. Bus. Br. 2005, 2, 1-3.

3. Sweeney, M. (Ed.) Terrain and Geohazard Challenges Facing Onshore Oil and Gas Pipelines; Thomas Telford: London, UK, 2005; p. 758.

4. Lee, E.M. Landslide risk assessment: The challenge of estimating the probability of landsliding. Q. J. Eng. Geol. Hydrogeol. 2009, 42, 445-458. [CrossRef]

5. Young, A.; Lockey, A. The assessment of pipeline integrity in geohazard areas using ILI data. In Proceedings of the ASME 2013 International Pipeline Geotechnical Conference, Bogota, Colombia, 24-26 July 2013; p. V001T02A008.

6. Dai, F.C.; Lee, C.F.; Ngai, Y.Y. Landslide risk assessment and management: An overview. Eng. Geol. 2002, 64, 65-87. [CrossRef]

7. Erener, A.; Düzgün, H.B.S. A regional scale quantitative risk assessment for landslides: Case of Kumluca watershed in Bartin, Turkey. Landslides 2013, 10, 55-73. [CrossRef]

8. Fell, R.; Corominas, J.; Bonnard, C.; Cascini, L.; Leroi, E.; Savage, W.Z. Guidelines for landslide susceptibility, hazard and risk zoning for land use planning. Eng. Geol. 2008, 102, 85-98. [CrossRef]

9. Yamagishi, H.; Moncada, R. TXT-Tool 1.081-3.1 Landslide Recognition and Mapping Using Aerial Photographs and Google Earth, Landslide Dynamics: ISDR-ICL Landslide Interactive Teaching Tools; Volume 1: Fundamentals, Mapping and Monitoring; Springer: Cham, Switzerland, 2018; pp. 67-82.

10. Guzzetti, F.; Reichenbach, P.; Cardinali, M.; Galli, M.; Ardizzone, F. Probabilistic landslide hazard assessment at the basin scale. Geomorphology 2005, 72, 272-299. [CrossRef]

11. Guzzetti, F.; Mondini, A.C.; Cardinali, M.; Fiorucci, F.; Santangelo, M.; Chang, K.T. Landslide inventory maps: New tools for an old problem. Earth-Sci. Rev. 2012, 112, 42-66. [CrossRef]

12. SafeLand. Guidelines for landslide susceptibility, hazard and risk assessment and zoning. In Living with Landslide Risk in Europe: Assessment, Effects of Global Change, and Risk Management Strategies, Deliverable D2.4; EU-FP7 SafeLand Project, Ed.; SafeLand; Norwegian Geotechnical Institute: Stryn, Norway, 2011; 173p.

13. Cardinali, M.; Reichenbach, P.; Guzetti, F.; Ardizzone, F.; Antonini, G.; Galli, M.; Cacciano, M.; Castellani, M.; Salvati, P. A geomorphological approach to the estimation of landslide hazards and risks in Umbria, Central Italy. Nat. Hazards Earth Syst. Sci. 2002, 2, 57-72. [CrossRef]

14. Cruden, D.M.; Varnes, D.J. Landslides types and processes. In Landslides: Investigation and Mitigation; Turner, A.K., Schuster, R.L., Eds.; National Academic Press: Washington, DC, USA, 1996; pp. $35-76$.

15. Carrara, A.; Crosta, G.B.; Frattini, P. Geomorphological and historical data in assessing landslide hazard. Earth Surf. Process. Landf. 2003, 28, 1125-1142. [CrossRef] 
16. Klose, M.; Damm, B.; Highland, L.M. Geohazard Databases: Concepts, Development, Applications. Geomorphology 2015, 249, 1-136. [CrossRef]

17. Piacentini, D.; Troiani, F.; Daniele, G.; Pizziolo, M. Historical geospatial database for landslide analysis: The Catalogue of Landslide Occurrences in the Emilia-Romagna Region (CLOCkER). Landslides 2018, 15, 811-822. [CrossRef]

18. Ghosh, S.; van Westen, C.J.; Carranza, E.; Jetten, V. Integrating spatial, temporal, and magnitude probabilities for medium-scale landslide risk analysis in Darjeeling Himalayas, India. Landslides 2011, 9, 371-384. [CrossRef]

19. O.G.S. Seismological Report for Albania; TAP: Lisbon, Portugal, 2013.

20. Hoek, E.; Brown, E.T. Hoek-Brown failure criterion and, G.S.I-2018 Edition. J. Rock Mech. Geotech. Eng. 2018, in press. [CrossRef]

21. Hoek, E.; Carranza-Torres, C.; Corkum, B. Hoek-Brown criterion-2002 edition. In Mining and Tunnelling Innovation and Opportunity, Proceedings of the 5th North American Rock Mechanics Symposium and 17th Tunnelling Association of Canada Conference, Toronto, ON, Canada, 7-10 July 2002; Hammah, R., Bawden, W., Curran, J., Telesnicki, M., Eds.; University of Toronto: Toronto, ON, Canada, 2002; Volume 1, pp. 267-273.

22. Varnes, D.J. Slope movement types and processes. In Landslides-Analysis and control: National Research Council; Special Report 176; Schuster, R.L., Krizek, R.J., Eds.; Transportation Research Board: Washington, DC, USA, 1978; pp. 11-33.

23. Uzielli, M.; Nadim, F.; Lacasse, S.; Kaynia, A.M. A conceptual framework for quantitative estimation of physical vulnerability to landslides. Eng. Geol. 2008, 102, 251-256. [CrossRef]

(C) 2019 by the authors. Licensee MDPI, Basel, Switzerland. This article is an open access article distributed under the terms and conditions of the Creative Commons Attribution (CC BY) license (http:/ / creativecommons.org/licenses/by/4.0/). 